\title{
Irmandades e Ritual em Minas Gerais durante o Período Colonial O Triunfo Eucarístico de 1733
}

Maria Alice Volpe

O presente artigo propõe uma abordagem de orientação etnomusicológica para um assunto que tem sido tratado como objeto exclusivamente histórico. Musicólogos têm empreendido a árida tarefa de recuperar a produção musical de Minas Gerais durante o período colonial, e estudos de análise estilística permanecem extremamente necessários. Embora tal período ainda apresente lacunas sobre sua organização e produção musical, os conhecimentos atuais já permitem uma tentativa de reconstrução da sua dinâmica como sistema cultural. Isto requer o auxílio de disciplinas como a história política e econômica, a sociologia e a antropologia cultural, assim como os estudos sobre as religiões. $\mathrm{O}$ presente artigo seleciona alguns dos aspectos considerados relevantes para uma teoria interpretativa da cultura onde a música se inseria, utilizando-se da perspectiva oferecida por estudos básicos realizados pelas disciplinas mencionadas. Propõe, ainda, um estudo ritual da música e das irmandades de Minas Gerais durante o período colonial, sob a perspectiva institucional e da prática da performance, analisando convenções e simbolismos que refletem as relações sociais dominantes na época em questão. A abordagem institucional oferece acesso a aspectos normativos da atividade musical e dos 
valores culturais, enquanto a prática da performance propicia o estudo de uma rede de simbolismos envolvidos na dinâmica de negociação entre os vários segmentos daquela sociedade. O estudo ritual, neste artigo, analisa os mecanismos simbólicos que legitimam ou desafiam a ordem social e procura explorar o sentido potencialmente associado aos objetos e atos rituais. A última parte do presente artigo apresenta uma análise das festividades do Triunfo Eucarístico de 1733, segundo a orientação teórica exposta acima.

O contexto cultural no qual a música estava envolvida em Minas Gerais, durante o século XVIII e grande parte do século XIX, estava estreitamente ligado às Irmandades. Tais instituições foram uma das respostas mais significativas para uma rede de problemas enfrentados por uma sociedade mais democrática e miscigenada, que desabrochou com a economia mineradora e cuja vida política e religiosa estava fundada no sistema do Padroado.

\section{O Padroado}

O sistema do Padroado consistia num acordo entre a Igreja Católica Romana e o Reino de Portugal, pelo qual o papa transferia ao rei a administração temporal da Igreja Católica em territórios portugueses. Essa aliança fundava-se numa reciprocidade de interesses e suporte mútuo. De um lado, o estado português tornava possível a difusão da fé católica em seus novos territórios; por outro lado, a Igreja legitimava e sacralizava o poder do rei, assumindo um papel conciliatório entre conquistador e conquistado, senhores e escravos, por meio da ideologia religiosa. O Padroado vigorou em Portugal por quase oito séculos, do início do século XII ao início do século $\mathrm{XX}$, sendo eliminado gradualmente nas diversas colônias desde o século XIX. A complexidade do seu funcionamento deve-se não apenas ao fato de as condições econômicas, políticas e sociais terem mudado no decorrer desse longo período, como também à variação das condições locais, que resultavam em idiossincrasias na relação entre Igreja e Estado, Igreja 
e povo, Estado e povo, e Estado-Igreja e povo. Tais diferenças locais são relevantes para o estudo da música e do ritual, pois esses fatores múltiplos repercutem na organização da vida religiosa e secular, tanto no nível institucional quanto no da prática da performance, seja nos eventos musicais relacionados direta ou indiretamente, e até não relacionados com as celebrações religiosas.

O sistema do padroado concernente ao territórios coloniais portugueses foi instituído por bulas decretadas por quatro pontífices, entre 1455 e 1515, e vigiu no Brasil ainda após a Independência (1822) até, mesmo, após o fim do Império (1889). O rei de Portugal e seus sucessores obtiveram um duplo padroado: o secular, que dava suporte ao seu poder político na qualidade de rei, e o espiritual, que garantia seus benefícios como Grão-Mestre da Ordem de Cristo e administrador de todas as jurisdições episcopais ordinárias nos territórios portugueses (BRUNEAU, 1982: 14)1. A Carta Real de 1632, válida em todos os territórios de além-mar, estabeleceu o regime das conhecenças e das côngruas régias, de acordo com o qual o dízimo, um décimo de todo o ganho provindo de qualquer serviço religioso, até então coletado e administrado pelas Igrejas e seus ministros, tornou-se um dízimo real e, portanto, coletado pela Corôa (CARRATO, 1968: 55), a qual se comprometia a construir igrejas, manter seminários e conventos, remunerar os clérigos e dar suporte financeiro ao culto e festividades religiosas. "A mistura dos dízimos com o tesouro real (...) levou facilmente a consideráveis abusos" (BRUNEAU, 1982: 15) e a Corôa nem sempre cumpriu com seus deveres, o que levou a uma série de distorções e transferência de obrigações e funções. Entre os resultados estão o poder político legislando assuntos, contendas e celebrações religiosas como, por exemplo, "o direito de recurso à Corôa em casos de disciplina eclesiástica. Se um membro da Igreja era punido pelo superior de uma ordem ou bispado, ele podia recorrer à Corôa. Isso significava que a Igreja não podia efetivamente gerir a disciplina" (BRUNEAU, 1982: 14). O poder de decisão final do estado sobre a Igreja será abordado, neste artigo, no final desta seção sobre a celebração do dia de Santo Antônio no Arraial do 
Tejuco em 1799, e na seção dedicada à análise do Triunfo Eucarístico, mostrando como essa relação de poder se expressa simbolicamente naqueles rituais.

Outra conseqüência do sistema do Padroado foi a laicização do clero. Religião tornou-se serviço de Estado, carreira eclesiástica transformou-se em serviço público e a Igreja era vista como um setor da burocracia civil (TORRES, 1968: 32-33). Torres (1968: 35-39) chama esta situação do Padroado de "o grande paradoxo", onde clérigos eram pagos para ministrar os sacramentos da mesma forma que os juízes eram pagos para ministrar a justiça e os militares para proteger e lutar. As leis da Igreja eram oficialmente reconhecidas pelo Estado e tinham força suprema; crimes contra a fé e costumes católicos eram investigados pelo Santo Oficio e corrigidos pelo "braço secular" com a mais dura punição. Feriados religiosos eram feriados cívicos; certidão de nascimento e idade eram fornecidos pelo batismo; o matrimônio era legitimado e oficializado apenas pela Igreja, e existiam apenas cemitérios religiosos. Não havia nenhum aspecto da vida civil que não fosse abençoado pela Igreja.

A reciprocidade entre Corôa e Igreja, poder político e religioso é expressa simbolicamente em grande parte dos rituais durante o período colonial. A superposição dos dois âmbitos, o político e o religioso, ou seja, o caráter cívico presente em festas que, em princípio, têm origem e função religiosa, reflete a intensa interação entre a religião portuguesa e suas instituições políticas. A identificação da esfera política e religiosa resultou de um longo processo histórico. O próprio reconhecimento de Portugal como nação independente foi possível graças à aliança estabelecida entre D. Afonso Henriques e a Santa Sé, em 1143: o rei de Portugal "jurou obediência à Santa Sé e colocou seu reino sob a proteção de São Pedro e da Corte Papal Romana." (NOGUEIRA, 1941: 7). No entanto (ainda conforme NOGUEIRA, 1941: 7), o suporte ideológico católico não teria tido sentido se não tivesse correspondido à religiosidade popular. A identidade nacional portuguesa e sua visão de mundo foram historicamente fundadas 
no sistema de crenças católico, e todo evento da sua vida secular repercutia na sua vida religiosa e vice-versa.

\section{As Festas Maiores}

A identificação entre spirinualis e temporalis reflete-se nas principais celebrações efetuadas em Minas Gerais durante o período colonial, sobretudo nas oficiais, de natureza cívica e religiosa, e referidas na literatura coetânea como festividades cívico-religiosas. O calendário das festividades cívico-religiosas era composto das "festas maiores" e das "festas menores". As "festas maiores" incluíam as quatro festas mandatícias e a festa do santo patrono local. As "festas maiores", tanto do ponto de vista de organização como de função e significado, eram a representação simbólica mais completa do sistema do Padroado, segundo o qual a Corôa Portuguesa e a Igreja Católica vinculavam-se. A Corôa Portuguesa determinava quatro festas oficiais mandatícias: Corpus Christi, São Sebastião, Nossa Senhora da Conceição e São Francisco de Borja; houve um período em que as Ladainhas dos Sábados também eram requeridas (LANGE, 1966: 62). Corpus Christi era tida como a festividade mais importante. Ela celebra o Santíssimo Sacramento, o mais sagrado sacramento, o mistério da transmutação do pão e do vinho no corpo e sangue de Cristo, e constitui um dos dogmas católicos mais importantes. A celebração da Eucaristia funcionava como a confirmação da fé católica e, analogamente, como ratificação do poder monárquico. Toda e qualquer cerimônia confirmando o catolicismo ratificava potencialmente o poder monárquico, mas a festividade de Corpus Christi tinha um significado especial, uma vez que a transmutação de substância ordinária em divina servia como metáfora simbólica da transmutação do poder temporal do rei em poder divino.

A legitimação do poder real através da associação do divino também tem raízes no messianismo que marcou profundamente as concepções e expectativas durante os séculos XVI e XVII. A devoção a São Sebastião reflete a interação entre messianismo e a 
congruência do poder temporal e espiritual; associa-se ao rei Dom Sebastião, "o rei encoberto", que empreendeu uma expedição à África, onde morreu, no século XVI. "Não tendo o seu corpo sido identificado com facilidade após o combate, logo surgiram vozes que ele teria desaparecido a cavalo, para voltar posteriormente e salvar o reino" (AZZI, 1987: 59). O mito de São Sebastião surgiu de um episódio elaborado simbolicamente como um "rito de passagem"2: o rei empreendeu a Guerra Santa de conquista e conversão como servus servorum Dei, num estado liminar onde "a suprema autoridade política é representada "como um escravo"" de Deus (TURNER, 1969: 102)3. A perda de status é seguida de morte fisiológica, momento crucial de colapso, que leva à transição de um estado inferior para um superior, onde o sujeito (o rei) recebe poder sobrenatural e se torna um santo. Dom Sebastião tornou-se um mito messiânico que voltaria no futuro para liberar o povo português do sofrimento, transformando Portugal numa grande nação.

Conforme Torres (1968: 61-67), Dom Sebastião é o arquétipo do herói salvador, o líder messiânico; o messianismo "coloca sua esperança no domínio terrestre" e "tem como fulcro um indivíduo que se acredita possuir atributos sobrenaturais e que vaticina catástrofes de que só se salvarão seus adeptos". O cataclismo pode ser considerado um "rito de passagem" coletivo, que seleciona apenas aqueles que estão "de acordo com certas normas de costumes e padrões éticos" (TURNER, 1969: 95), neste caso, o catolicismo. Aqueles que são bem sucedidos no "rito de passagem", isto é, os que sobrevivem ao cataclismo, fundarão um reino sagrado neste mundo, criando um novo milênio histórico, sob a direção do Messias. De acordo com Torres (1968: 61-67), uma vez que adeptos católicos não poderiam ter fé num Messias que não fosse Jesus, foi criada uma "solução intermediária: um Imperador cristão, portabandeira do Cristo que implantasse no mundo a verdade cristã". O milagre da ressurreição do rei de Portugal destruiria a heresia, o paganismo e a infidelidade dos judeus (TORRES, 1968: 61). A interpretação proposta por Torres mostra que o mito de São 
Sebastião foi extremamente significativo para o espírito conquistador português, já que sua expansão territorial, dominação política e atitude colonialista justificavam-se pela sagrada missão da conversão. Essa ideologia expressou-se simbolicamente através de uma cerimônia que resultou em uma das quatro "festas maiores", o dia de São Sebastião (20 de Janeiro).

A crença em milagres é outro aspecto da religiosidade portuguesa e está presente não apenas no mito de Dom Sebastião, como também na devoção a muitos santos. São Francisco de Borja é um santo jesuíta que morreu como mártir no Japão, no século XVI, e teve um significado especial para o português do século XVIII, porque foi atribuído a ele o milagre de salvar a população de Lisboa no terremoto de 1755. Desde então, o dia do seu onomástico, 10 de outubro, foi incluído nos feriados e festividades oficiais. Este mito também é elaborado como "rito de passagem", pois a mudança de estado ocorre por "liminaridade" (martírio e morte) e "elevação de slatus" (santificação); o "rito de passagem" está também presente em nível coletivo, como catástrofe (terremoto) e sobrevivência. Catástrofe pode ser considerada um "espaço liminar", pois suspende (momentaneamente) as categorias da estrutura hierárquica da sociedade, onde todos os membros da comunidade são colocados em situação de igualdade ante a ameaça de integridade física e potencial perda da vida, uma situação contingente que reduz todos a meros mortais e que gera uma revitalização do senso de communitas.

O culto à Virgem Maria é outra característica importante da religiosidade portuguesa e estava presente no calendário oficial tanto na festa de Nossa Senhora da Conceição como na Ladainha dos Sábados, relacionado, nos países ibéricos, com o Rosário das Auroras; é uma devoção mariana dedicada à dimensão feminina da divindade, uma figura maternal de devoção e proteção. Nossa Senhora é invocada sob vários títulos e não é mais a figura hierática dos tempos medievais, mas a mãe de Jesus, com sentimentos humanos, a Virgem que abraça ternamente seu Filho Sagrado e sofre Seu sacrificio na cruz como mãe humana, mas resignada como 
uma santa (CARRATO, 1968: 32). Entre as muitas qualidades atribuídas a Nossa Senhora e explicadas no marianismo, a devoção à Imaculada Conceição se destaca por referir-se a outro dogma católico, o mistério da Virgem que concebe o Filho de Deus. Nossa Senhora da Conceição é a padroeira do reino português, da Casa de Bragança e é estimada pela religiosidade popular portuguesa como a mãe da humanidade, madrinha e padroeira das mulheres, madrinha e namorada dos homens (CARRATO, 1968: 32). O dia da Imaculada Conceição é celebrado a 10 de dezembro; sua devoção pode ser considerada a contrapartida feminina da devoção a São Sebastião; a figura materna da proteção, fertilidade e amor, complementando a figura masculina do guerreiro que vence a peste, a fome e a heresia.

As celebrações oficiais mencionadas constroem-se num sistema de mitos que tende a divinizar a figura do rei e humanizar as figuras sagradas. Os santos, a Virgem e até mesmo Deus, na figura de Jesus, passam por um processo de humanização pelo qual se transferem atributos humanos a entidades que pertencem ao domínio sagrado. A figura divinizada do rei nunca é disputada pela onipotente figura de Deus, uma vez que a suprema entidade sobrenatural é invocada no dogma abstrato da Sagrada Eucaristia ou na figura tangível de Jesus humanizado. Além disso, todo o sistema de mitos reflete a própria historicidade do povo português, cujos valores foram fortemente afetados pelo movimento da ContraReforma e pela ideologia da conversão, e amalgamados com suas experiências particulares de identidade nacional, expectativas, frustrações, catástrofes, realizações e conquistas.

A celebração do padroeiro local é também parte das "festas maiores" e varia de uma vila para outra. Por exemplo, o santo padroeiro de Vila Rica (Ouro Preto) era Nossa Senhora do Pilar; o do Arraial do Tejuco (Diamantina) era Santo Antônio (LANGE, 1966: 62). O estudo das origens e motivações dessas devoções envolve muitas vilas com processos específicos de povoamento, construção de identidade e representação de grupos sociais, e requer um nível mais detalhado de especificidade cultural, cujo estudo extrapola os propósitos deste artigo. 
As motivações gerais para o sistema simbólico expresso nas festividades oficiais mandatícias baseavam-se na ideologia monárquica e colonizadora, no espírito da Contra-Reforma, na historicidade desses povos e na especificidade da religiosidade popular. Além das festividades oficiais, existiam também as chamadas "eventuais", isto é, eventos ocasionais relacionados com a vida política e religiosa como, por exemplo, a chegada de um novo Governador Geral ou Bispo, a visita de autoridade política ou religiosa, ou acontecimentos importantes na Metrópole, como a doença ou morte do soberano, nascimento ou casamento de príncipe ou princesa, aclamação do rei e outros (LANGE, 1966: 62). As festividades oficiais relacionadas com a Metrópole tinham a intenção de mostrar reverência ao soberano, consideração pelos eventos concernentes a ele e sua família, e expressar vassalagem. As motivações das festividades oficiais locais incorporam a dinâmica particular de cada vila, refletindo os valores em jogo em momentos particulares da realidade de cada vila. A vida ritual em Minas Gerais, durante o período colonial, teve algumas particularidades diretamente relacionadas com o processo de povoamento da região, tanto em termos de atividades econômicas como dos grupos étnicos ali formados.

\section{Diferenças Sociais}

A sociedade mineira do século XVIII desenvolveu-se a partir de um crescente processo de miscigenação, muito mais intenso do que em núcleos populacionais da área litorânea. Tal processo resultou numa sociedade muito mais heterogênea, cujo fenômeno marcante foi o chamado "mulatismo". Além disso, a economia mineradora criou uma sociedade cuja característica distinta da economia agrária da costa nordestina foi a maior rapidez de mobilidade social. O poder econômico não dependia apenas da propriedade da terra, uma concessão dada pelo monarca para algumas famílias de aristocratas. A exploração das minas possibilitou o enriquecimento de muitas pessoas que não tinham o privilégio 
dos latifúndios. De certa forma, a oportunidade de ascensão econômica foi democratizada e, uma vez adquirido poder econômico, a ascensão social e a aquisição de poder político eram um passo muito pequeno. Por outro lado, a mineração era negócio de alto risco e podia levar à ruína econômica. Se na sociedade agrária do nordeste brasileiro as relações eram estreitamente sujeitas a uma divisão imutável entre senhor e escravo, a qual levava a uma atitude opressiva do português sobre o africano e seus descendentes, a instável sociedade do ciclo do ouro no interior do Brasil desenvolveu uma relação mais flexível e tolerante entre as classes sociais e grupos étnicos. Além disso, a sociedade mineira cresceu numa forma mais urbanizada, criando uma série de atividades e categorias profissionais paralelas, como comerciantes, artesãos e profissionais liberais, o que resultou numa relativa democratização de oportunidades envolvendo mulatos e suscitando-lhes um melhor status social. Após a década de 1750, a população das Minas Gerais era fortemente composta de mulatos, que legitimaram sempre mais seus direitos de manter cargos, anteriormente prioridade dos brancos. Outro expressivo contingente étnico da sociedade das Minas Gerais era a população negra, representando mais de 50\% do total na primeira metade do século XVIII. Estes eram predominantemente escravos, mas em muitos casos, negros alforriados, libertos, aos quais se tinha concedido ou vendido a liberdade.

A discriminação social existiu em Minas Gerais numa larga variedade de nuanças. A chamada "infâmia de sangue" contra judeus e negros estendia-se aos casais e descendentes. Um português vivendo com mulher negra era discriminado por "infâmia de sangue", vedando-se-lhe o exercício dos direitos de português. No entanto, o mulato podia entregar-se a atividades em princípio exclusivas de portugueses, como posições administrativas, judiciais e fiscais. A flexibilidade da situação do mulato devia-se a muitos fatores: a religião católica conferia ao português uma relativa tolerância racial, devida ao fato de que "o português, no período da conquista, não era um grupo racialmente homogêneo, e sua 
cultura era o resultado de contatos com fenícios, romanos, cavaleiros franceses e ingleses, mouros, judeus e negros" (SCHWARTZ, 1995: 30) ${ }^{4}$. Por outro lado, a adoção do sistema de crenças católico por parte dos mulatos legitimava o reconhecimento de seu lugar na sociedade dominada pelo branco.

A situação do mulato era ambígua, como pessoa "notoriamente defeituosa e maculada" (conforme linguajar da época; ver LIMA JÚNIOR, 1965: 125), mas que "nascia um europeu na língua, nos costumes, na religião, na mentalidade, apagando-se na primeira geração os traços intelectuais da raça de Cam, que só perdurava no tipo antropológico de transição". (LIMA JÚNIOR, 1965: 123). Oportunidades variavam conforme as circunstâncias; ilustra-o um caso em Vila Rica em 1725: um mulato foi eleito Juiz Ordinário, provocando escândalo e protesto entre as "pessoas puramente brancas". A autoridade local, isto é, o Capitão-General, impôs sua aceitação, mas a população branca apelou diretamente ao rei de Portugal. O Conselho Ultramarino despachou: "porque se a falta de pessoas capazes fez a princípio necessária a tolerância de admitir mulatos ao exercício daqueles ofícios, hoje, que tem cessado essa razão, se faz indecoroso que eles sejam ocupados por pessoas em que haja semelhante defeito". Nesse documento alegase, também, que a autoridade dos mulatos não era respeitada, o que provocava "desordens nos povos e perturbação na boa administração da Justiça". O Conselho Ultramarino ordenou ao Governador Geral das Minas "que não se possa daqui em diante ser eleito Vereador ou Juiz Ordinário, nem andar na Governança das Vilas daquela Capitania, homem algum que seja mulato dentro dos quatro graus em que o mulatismo é impedimento, e que da mesma sorte não possa ser eleito ...". A decisão real, neste caso, não é conhecida. (LIMA JÚNIOR, 1965: 124-5)

No entanto, a discriminação contra o mulato não era exclusivamente um problema de atitude coletiva, mas dependia também de interesses individuais. Muitas vezes, um pai português usava seu prestígio para colocar seu talentoso filho mulato num cargo judicial, administrativo ou político, porque isso garantiria 
seu poder contra grupos antagônicos, estes na maior parte das vezes compostos também por pessoas brancas. Havia uma diversidade de nuanças no nível de integração do mulato na sociedade dominante branca, uma vez que o acesso aos seus beneficios não dependia apenas de questões de sangue mas de uma série de circunstâncias particulares. Ser filho de branco com negra podia implicar maiores restrições se comparado a um filho de branco com mulata, pois o último está naturalmente mais esbranquiçado que o primeiro. A integração do mulato também dependia do status de seu pai branco e do reconhecimento da paternidade pelo pai, ainda que condicionado por conveniências sociais. Um pai branco de alta posição social podia constranger-se mais em assumir publicamente um filho de sangue negro, o que restringia as possibilidades do descendente se projetar socialmente, coisa em princípio reservada aos brancos e cujo acesso esteve muitas vezes ligado à influência do prestígio paterno. Com freqüência, o descendente mulato não era reconhecido publicamente, tendo acesso a certo nível de instrução graças a um sistema de educação muito comum nos tempos coloniais, as "escolas domésticas", conduzido pela mãe e realizado basicamente em casa, e a schola cathedralis, onde ensinava o padre-mestre, capelão ou padre-cura (sobre o sistema educacional em Minas Gerais durante o período colonial, ver CARRATO, 1968: 96-101). Mesmo considerando um grupo étnico homogêneo composto por mulatos, a discriminação teve muitos graus, como "pardos escuros" e "pardos claros". A primeira geração de miscigenação sofria restrições muito maiores do que as seguintes gerações esbranquiçadas.

As relações de poder não eram apenas um assunto de pele branca ou negra; havia antagonismo entre brancos e, consequentemente, outros parâmetros de discriminação étnica estavam em jogo. Conforme Lima Júnior (1965: 128), no começo da colonização existia uma distinção entre pessoas brancas, os 'cristãos velhos' e os 'cristãos novos', estes, judeus que aceitavam o batismo e seus descendentes. Essa distinção foi-se extinguindo muito lentamente e desapareceu apenas no último quartel do século 
XVIII. Havia também um sentido diferente de pertença, que cada grupo atribuía a si mesmo e aos outros grupos. Os paulistas, ou seja, os bandeirantes descobridores das minas, consideravam-se mais proprietários do que os grupos chegados depois. Entretanto, os Emboabas, termo geralmente aplicado aos reinóis e brasileiros da Bahia, Rio de Janeiro e Pernambuco, disputaram as reivindicações paulistas e os derrotaram na famosa Guerra dos Emboabas (1709), que resultou na expulsão dos paulistas para o sul da região das Minas Gerais e na separação desta da Capitania de São Paulo, em 1720. Os portugueses chegados a essa região diretamente de Portugal buscando enriquecimento legitimavam suas aspirações pelo fato de que a sua nação tinha descoberto e colonizado o Brasil e que, portanto, eles eram os vassalos mais diretos do Rei.

O poder econômico era um outro importante parâmetro de diferenciação. Conforme Lima Júnior (1965: 129), a separação econômica acentuou-se com o tempo, resultando na principal e quase única diferenciação. Os "pés-rapados" eram o "poviléu", o branco pobre, negro ou mulato que vivia nas áreas baixas ou afastadas. Em situação oposta encontrava-se a nobreza, vivendo nos pontos altos da vila. Entre "os de cima" e "os de baixo", havia os "sem-nome", isto é, os portugueses das classes populares que não tinham um sobrenome respeitável. Havia também os "enjeitados", bastardos que usavam o sobrenome dos que os abrigavam ou, mais freqüentemente, um nome de santo como Conceição, Santo Antônio, Encarnação e assim por diante (LIMA JÚNIOR, 1965: 129). Essa distinção econômica envolvia também um status adquirido da linhagem de família, o que simplesmente não estava em jogo entre os grupos heterogêneos dos "pésrapados". Os "sem-nome" estavam numa posição inferior em comparação com a nobreza, mas também eram portugueses. Eles não tinham um nome de prestígio de que se orgulhar mas ainda tinham a dignidade de ser portugueses. Os "enjeitados" vinham de origem suspeita e toda oportunidade de integrar-se na vida social era vista como uma atitude benevolente da sociedade católica. Sobre todo esse caldeirão havia os nobres ricos. Cabe esclarecer como o 
conceito português de nobreza não implicava necessariamente "limpeza de sangue". Lacombe (1983: 99) enfatiza que a política portuguesa de concessão de honrarias incluía mestiços entre os mandarinos, o que anulava o caráter racista da instituição. Citando Capistrano de Abreu "a nobreza não era uma casta exclusiva; abriam para ela várias portas", entre elas a carreira eclesiástica (bispo), militar (general, almirante), judicial (magistrados dos tribunais superiores), política (governador, vereador) e as letras. No processo de "branqueamento", o branqueado mulato podia ingressar na classe da nobreza.

\section{As Irmandades}

Os diversos grupos emergentes nessa sociedade heterogênea organizaram-se em torno das irmandades, associações de leigos, de caráter religioso, cuja função extrapolava os propósitos devocionais. As irmandades reuniam classes sociais, grupos étnicos e categorias profissionais que compartilhavam preocupações, e sob a devoção de um santo padroeiro, agiam em muitos domínios da vida da comunidade, secular e religioso, coletivo e individual, os quais eram concebidos como intrínseca e mutuamente relacionados. As irmandades também tiveram um papel decisivo nas atividades musicais das Minas Gerais, pois, na ação de promover e estipendiar os rituais musicais, acabou estabelecendo e organizando a música no nível profissional.

A irmandades originam-se das Ordens Terceiras. A Ordem Primeira é a Ordem Regular Masculina, composta de monges, como os franciscanos, carmelitas, beneditinos e jesuitas, os quais vivem em comunidade e professam votos perpétuos. A Ordem Segunda é a Ordem Regular Feminina, composta de freiras que, como os monges, têm uma vida reclusa nos conventos. A Ordem Terceira é composta por leigos, homens e mulheres, como a Ordem Terceira do Carmo e a Ordem Terceira de São Francisco. Os beneditinos e jesuitas nunca tiveram Ordem Terceira. Outras associações de leigos, chamadas de Irmandades ou, quando "eretas ainda mais 
para o incremento do culto público", de Confrarias (SALLES, 1963: 16), eram formadas não sob uma certa Ordem, mas sob a devoção de um santo, a Virgem ou Jesus. A hierarquia entre essas associações religiosas seguia os estatutos da Sé Apostólica, em decrescente ordem de importância: Ordens Terceiras, Arquiconfrarias, Confrarias e Irmandades, e Pias Uniões (para um detalhamento, ver SALLES, 1963: 15-19)5.

As irmandades em Minas Gerais tiveram uma função social muito diversa das irmandades litorâneas, sobretudo devido à ausência do clero regular na região mineira, uma vez que conventos e mosteiros foram proibidos nas Minas Gerais por motivos religiosos e econômicos. Nas primeiras décadas da exploração do ouro, monges se dirigiram à região das minas sob pretexto de pregar a fé católica entre aquelas "pessoas rudes obcecadas pela promessa do ouro". No entanto, muitos deles foram às minas pelo mesmo motivo que todos os outros aventureiros e não trabalharam a favor da religião. Outros, simplesmente evadiram-se dos mosteiros e abandonaram a vida religiosa, resultando numa perda de recursos humanos para a Igreja Católica.

Muitos desses monges caíram numa vida pecaminosa de avidez e promiscuidade, criando uma situação que denegria a imagem da Igreja Católica. Esses monges geraram problemas para a Corôa, envolvendo-se no contrabando de ouro. Tudo indica que esse comércio ilegal teve uma estratégia muito bem estruturada, envolvendo conventos e mosteiros situados em áreas fluviais, como em Penedo, Alagoas, no Rio São Francisco, e na costa, como em Parati, no litoral sul do Rio de Janeiro. Esses monges desafiaram literalmente as Ordenações Filipinas, recusando-se a pagar o "quinto" ao Tesouro Real, induzindo as pessoas a fazerem o mesmo. A Carta Real de 6 de Junho de 1711 proíbe a presença de monges na Capitania das Minas Gerais: "que não consintais que nas Minas assista frade algum, antes os lance fora todos por força ou violência, se por outro modo não quiserem sair", e que o mesmo execute com "todos os clérigos que não tiverem ministério de párocos nominados pelo ordinário" (VASCONCELLOS, 1948, vol. II: 201). 
A reiteração do despacho oficial em 1715 e 1721, demonstra sua transgressão. Entretanto, isto não altera o fato de que o clero regular não teve uma ação institucionalizada oficialmente nas Minas Gerais e que sua função sócio-econômica tinha que ser substituída de alguma forma.

O clero secular do hábito de São Pedro, ordenado fora das Ordens e vivendo fora dos mosteiros, no mundo secular das paróquias, era responsável pela vida religiosa das Minas Gerais daquele tempo. A proibição de instalarem-se conventos e mosteiros nas Minas Gerais eliminou a presença do clero regular e estimulou a formação de irmandades. Do ponto de vista religioso, as irmandades serviram como um instrumento de propagação da fé católica e educação espiritual. Do ponto de vista secular, a sua ação preencheu uma série de demandas sociais, econômicas, éticas e ideológicas envolvendo a dinâmica interna daquela comunidade como também a Corôa. Conforme Salles (1963: 27), as irmandades assumiram o suporte financeiro de atividades que eram formal responsabilidade da Corôa, que transferiu a elas suas obrigações, e através delas, para a própria população de cada vila. Inversamente, tais grupos sociais conquistaram um instrumento de proteção de seus interesses: "A população (...) encontrava nestas corporações uma estrutura eficiente e legal, uma forma orgânica para expandir suas necessidades e reivindicações coletivas" (SALLES, 1963: 27).

As irmandades também funcionavam como instituições de previdência social: elas eram responsáveis pelo enterro dos membros, sepultura, "sufrágios" (um número de missas, variando de 10 a 40, aos membros falecidos), ajuda financeira às viúvas e crianças, assistência médica, assistência a crianças desamparadas e empréstimos a membros com dificuldades financeiras. A Irmandade do Santíssimo Sacramento do Pilar de Ouro Preto enviava uma enfermeira à casa dos seus membros doentes. A Irmandade da Santa Casa de Misericórdia de Ouro Preto, fundada em 1730 sob a devoção de N. Sra. Santana, construiu um hospital e atuou como instituição de caridade, atendendo a seus membros, a não-membros sob pagamento de taxa diária, e a pessoas destituídas de recursos, 
sem discriminação de nacionalidade ou religião. A Ordem Terceira do Carmo e a Ordem Terceira de São Francisco empreenderam atividade bancária, emprestando dinheiro a juros a seus membros. Ambas as irmandades tiveram tal poder econômico na segunda metade do século XVIII, que, em certa ocasião, foram implicitamente coagidas a emprestar ao governo da capitania "todo o cavedal que tiverem prompto, na referida moeda Barra (...) o importe em pó"; a Mesa de Irmãos reuniu-se no mesmo dia e despachou favoravelmente a tal solicitação (SALLES, 1963: 58). Alguns estudiosos têm sugerido que a fundação de certas irmandades foi motivada por propósitos políticos, como a Arquiconfraria dos Mínimos do Cordão de S. Francisco, composta basicamente por pardos, tendo aparecido simultaneamente (1760-1) em diversas vilas, como Ouro Preto, Mariana, Sabará e São João del Rei, mantendo coalizão regular entre as muitas unidades (TRINDADE, 1951: 91 e SALLES, 1963:37-8, 91). O vasto campo de ação dessas irmandades mostra quão indispensáveis elas foram para a dinâmica social, econômica e política daquela comunidade.

Outra importante contribuição das irmandades foi a formação de uma mentalidade mais democrática. Conforme Salles (1963: 19), "o poder ou autoridade de uma agremiação religiosa nada tinha a ver, em princípio, com seu sentido social", ou seja, "o grupo social, classe, camada ou estamento" que representava, mas seu "poder econômico e social expresso no número de irmãos arregimentados. (...) Não importava que ela fosse de brancos, pretos ou mulatos; importava seu poder como expressão desses grupos". A sociedade mineira, vivendo num regime monárquico, teve nas irmandades um instrumento mais democrático, que permitiu aos diversos grupos sociais negociarem seu espaço dentro da comunidade. A mentalidade democrática esteve presente também na própria organização interna das irmandades, uma vez que as decisões eram tomadas pela "Mesa de Irmãos", constituída através de eleições periódicas, em que todos os membros votavam (HOLLANDA, 1973: 125). Voto livre e igualdade de oportunidades eram garantidos pelo aparato legal: "A eleição será feita em escrutínio secreto, não 
só dos mesários atuais, como de todos aqueles Irmãos professos, que voluntariamente quiserem concorrer" (Capítulo $1^{\circ}$, artigo 5 da Ordem Terceira de N. S. das Mercê dos Perdões, de Antônio Dias, Ouro Preto, apud SALLES, 1963: 20). No entanto, o poder econômico era fator importante; quanto mais alta a posição o membro quisesse ocupar na hierarquia da irmandade, maior a sua contribuição financeira à instituição. O compromisso da Irmandade de São Benedito, de Mariana, de 1737, dizia: "Cada Irmão pagará de entrada uma oitava de ouro que se entregará ao tesoureiro ... e pagará anualmente outra oitava de ouro" (Capítulo $1^{\circ}$ ); e, em seguida, "Dará o Juiz, de esmola, no ano de seu juizado, vinte oitavas; o escrivão, dez oitavas; o tesoureiro, cinco oitavas; o procurador, cinco oitavas; os mordomos ou irmãos da Mesa, quatro oitavas cada um" (Capítulo 4º) (apud SALLES, 1963: 48). Fica claro, portanto, que embora todos os irmãos pudessem concorrer, a soma em dinheiro requerida para ocupar posições mais altas poderia ser um obstáculo a membros que não tinham recursos para sustentar tais obrigações monetárias. A autoridade dependia das qualidades pessoais que levariam membros a votar neste ou naquele, mas, de alguma forma, estava também vinculada ao poder econômico. No entanto, nas irmandades, poder econômico era usado com propósitos coletivos, pois tais associações funcionavam como cooperativas, nas quais toda contribuição monetária era transformada em patrimônio coletivo, que seria usado em benefício de todos os membros. Nesse sentido, poder econômico era traduzido em solidariedade, visto que todos contribuem para o bemestar de cada um e quanto mais se tem, mais se dá. Como Turner propõe, "communitas logo desenvolve uma estrutura" justamente vinda da "necessidade de mobilizar e organizar recursos para a busca de seus objetivos", e se transforma então em "communitas normativa" (1969: 132). As irmandades trouxeram também o princípio igualitário católico de humanidade, de acordo com o qual todos os que abraçam seu sistema de crenças é filho de Deus e deve ser tratado como tal. Este senso de humanidade estava potencialmente presente, pelo menos no domínio interno de cada 
irmandade, e constituía uma "communitas ideológica" (TURNER, 1969: 132-3) e que caracterizou uma dimensão constante de "liminaridade" compartilhada pelos "irmãos".

Ambas, communitas ideológica e normativa, eram extremamente importantes para os segmentos em algum tipo de desvantagem, particularmente econômica, étnica e situação social de escravo, porque tais communitas geravam uma democratização de participação na vida coletiva e também da expressão de necessidades, tendendo a compensar diferenças estruturais. Communitas ideológica e normativa criavam uma dimensão de homogeneidade entre os diversos segmentos daquela sociedade, polarizados nas irmandades, mas não geravam, no entanto, um "espaço liminar" no âmbito geral da sociedade, porque a identidade étnico-econômico-social procedia da diferenciação mais evidente e constituía o parâmetro segundo o qual irmandades se agrupavam e interagiam umas com as outras.

As irmandades eram expressão e reflexo de uma sociedade muito bem estruturada tanto em termos étnicos como de poder político, intelectual e econômico. A forma como as pessoas se reuniam em volta das irmandades enfatiza distinções estruturais, o que confirma a idéia de Turner (1969: 129) de que "maximização de communitas provoca maximização de estrutura". A Irmandade do Santíssimo Sacramento foi pioneira na instalação do clero nas Minas Gerais e geria a Igreja matriz; tal Irmandade representava os primeiros reinóis, magistrados e bandeirantes e não aceitava judeus e mulatos; entretanto, tendia a ser mais tolerante em relação à incorporação de "gente de cor" desde o final da década de 1750. A Ordem Terceira do Carmo e a Ordem Terceira de São Francisco de Assis, compostas por altos segmentos da sociedade, eram as mais radicais no que tange à raça e admitiam apenas "pessoas brancas puras". A Ordem Terceira do Carmo reunia sobretudo a classe de comerciantes, na qual predominavam os emboabas, mas abrigava também alguns intelectuais entre seus membros; essa irmandade parece ter sido a mais rica de Minas Gerais. A Ordem Terceira de São Francisco de Assis teve origem na "raça dos gigantes paulistas", 
os bandeirantes, e reunia sobretudo intelectuais, magistrados e governantes, mas também tinha comerciantes entre seus membros. A Ordem Terceira de São Francisco de Paula, a Arquiconfraria dos Mínimos do Cordão de São Francisco, a Irmandade de São José dos Bem-Casados e N. Sra. do Amparo, eram compostas por mulatos. As Irmandades de N. Sra. da Conceição, N. Sra. das Dores, São Miguel e Almas, São Pedro dos Clérigos, N. Sra. Santana, Bom Jesus dos Passos, São Gonçalo, N. Sra. Boa Morte, Bom Jesus dos Matosinhos, N. Sra. das Dores e N. Sra. da Expectação do Ó eram compostas por pessoas brancas. As Irmandades de N. Sra. do Rosário, S. Efigênia e S. Benedito eram compostas por negros escravos ou forros. Os "pretos creoulos", isto é, negros nascidos no Brasil, reuniam-se na Irmandade da Nossa Senhora das Mercês para se diferenciar dos africanos; esta diferenciação envolvia também status social, uma vez que aqueles pretos crioulos eram geralmente militares, enquanto os africanos eram escravos. A Irmandade de N. Sra. das Mercês podia ser também de pardos. Salles (1963: 45) conclui que, enquanto as corporações de brancos tenderam a proibir a entrada de pessoas originárias de "qualquer infecta nação", isto é, judeus, mouros e africanos, as irmandades de negros geralmente permitiram a entrada de qualquer indivíduo, inclusive a de brancos. A correspondência entre estratificação social e irmandades mostra a complexidade das relações sociais. "Os pésrapados, por mais brancos e puros de sangue que fossem, privavam socialmente com os pardos e os negros na convivência e nas Irmandades. Os mais intolerantes eram os negros, em cujas confrarias do Rosário não admitiam brancos, nem pardos" (LIMA JÚNIOR, 1965: 130). Tal intolerância não foi, no entanto, ostensiva: o compromisso de 1761 da Irmandade do Rosário, da matriz do Pilar, em Ouro Preto, afirmava a aceitação de "toda pessoa preta ou branca, de um e outro sexo, forro ou cativo, de qualquer nação que seja" (LOPES, 1955: 195). A classificação acima baseia-se em Salles (1963: 137-141), estudo exaustivo sobre as associações religiosas em Minas Gerais durante o ciclo do ouro, e Hollanda (1973: 124). 
Tornar-se membro de uma irmandade demandava o preenchimento de requerimentos cujo processo e efeito social podem ser considerados um "rito de passagem", no sentido definido por Turner (1969: 94), ou seja, ritos que têm por conseqüência uma mudança de estado. Quando consumado, o efeito social desse "rito de passagem" significava uma mudança de status do indivíduo e oferecia uma série de privilégios, como os mencionados anteriormente, dos quais não se usufruía antes. Era, na verdade, um "ritual de elevação de status" que, quando bem sucedido, isto é, se preenchendo o candidato todos os requisitos, "promovia a pessoa irreversivelmente de uma posição inferior para uma posição superior num sistema institucionalizado de tais posições" (TURNER, 1969: 167). O candidato submetia-se a uma comissão, que efetuava um processo investigatório sobre sua vida presente e pregressa. Devoção ao catolicismo, requerimento comum entre todas as irmandades, era um senso de humanidade compartilhado pela comunidade em geral, isto é, a communitas mais universal da sociedade mineira, ainda que a imposição deste sistema de crenças tenha ou não sido autoritária. A adesão ao catolicismo era comprovada por depoimento verbal ou escrito e envolvia um inquérito para que se constatasse se o candidato vivia de acordo com os princípios religiosos e morais da fé católica. Outros parâmetros de communitas eram mais específicos de cada irmandade. Além de religião, etnia parece ter sido o fator mais importante, embora, por vezes, ambos se sobrepusessem. A discriminação contra os "cristãos novos" atuava diferentemente em cada irmandade. A Irmandade das Almas, da Freguesia de Santo Antônio do Campo de Casa Branca (distrito de Ouro Preto), não aceitava o grupo étnico heterogêneo de pessoas recém-convertidas: "Os irmãos que se houverem de aceitar nesta nossa Irmandade serão conhecidos por cristãos velhos de limpo sangue" (Capitulo $4^{\circ}, 1720$, apud SALLES, 1963: 38). Algumas irmandades requeriam uma communitas que amalgamava raça, status religioso (ou seja, cristão novo ou velho) e status social. Como exemplo, o termo de ereção (1721) da Irmandade de Nosso Senhor dos Passos, da Freguesia 
de São José do Rio das Mortes, dizia: “Os Irmãos que se receberem hão de ser sem nenhum escrúpulo, limpos de geração; ou sejam nobres; ou oficiais; e dos que não forem nobres ou oficiais, não sejam a sua esfera menos que oficiais, e assim ... não [sejam]... raça de judeu, ou de Mouro, ou de mulato, ou de novo convertidos de alguma infecta nação..." (apud SALLES, 1963: 44). Havia irmandades que vedavam qualquer discriminação conquanto fosse provada a adesão ao catolicismo. O compromisso de 1795 da Irmandade do Rosário, em Tiradentes, afirmava: "É muito conveniente ao serviço de Deus e Nossa Senhora e ao bem das almas dos fiéis, que nesta Irmandade se aceitem por irmão todas as pessoas que, por devoção, quiserem servir a Nossa Senhora, tanto eclesiásticas como seculares; homens e mulheres, brancos, pardos e pretos, assim escravos, como forros sem determinar-se número certo de irmãos, senão os mais que puderem haver ..." (apud SALLES, 1963: 40). Nesse caso em particular, communitas residia não apenas no sentido unificado de humanidade conferido pela adesão ao catolicismo, mas também em diversidade; em outras palavras, a origem heterogênea de seus membros era fator de communitas. Este nível específico de communitas estabelecido por cada irmandade se refere ao que foi dito anteriormente, de que tais instituições consubstanciam uma expressão de uma sociedade estruturada.

Depois de se tornar membro de uma irmandade, isto é, uma vez que a passagem é consumada, o indivíduo "deve se comportar de acordo com certas normas costumeiras e padrões éticos" e "em virtude disso, tem direitos e obrigações vis-à-vis dos outros" membros (TURNER, 1969: 95). É necessário observar que, no caso das irmandades em Minas Gerais, a elevação de status não era absolutamente irreversível, uma vez que mau comportamento poderia resultar em expulsão, o que era sinônimo de perda de status. Um exemplo dessa dinâmica de aquisição, perda e recuperação de status ocorreu na Ordem Terceira de S. Francisco de Ouro Preto, em 1775, quando "com a presença de todos foi lida ... uma petição em nome do nosso irmão Antônio Dutra, em que nela expunha que 
pela Mesa pretérita que servia há vários anos fora avisado para não usar mais Nosso Santo Hábito em todas as festas e funções da ordem com o pretexto que se tinha casado com Mulher parda ao depois de ser professo há muito tempo, o que com efeito está desquitado dela há mais de nove ou dez anos, e que nunca mais a viu nem com ela conversara, e assim pedia que pelo amor de Deus o admitissem aos Santos exercícios desta venerável ordem; e depois de assim ser lida ... e à vista das informações que dele se havia, foi readmitido" (apud SALLES, 1963: 42).

Um dos papéis mais importantes das irmandades estava relacionado com a instalação da Igreja Católica nas Minas Gerais. Nos primeiros tempos, todas as Igrejas matrizes pertenciam à Irmandade do Santíssimo Sacramento (SALLES, 1963: 30). As irmandades poderiam estar ligadas à Igreja matriz tendo, dentro desta, um altar dedicado a seu padroeiro ou padroeira. As ricas Ordens Terceiras (Carmelitas e Franciscanos) e a maioria das Irmandades (entre elas, a Irmandade de Nossa Senhora das Mercês e Nossa Senhora do Rosário) construíam suas próprias Igrejas e capelas. Isto criou uma situação singular, uma vez que as irmandades eram responsáveis por todo o suporte financeiro de suas respectivas Igrejas, no que se refere tanto à "fábrica" da Igreja, isto é, contas diárias, quanto às "artes" construídas na Igreja (pagamento de arquitetos, escultores, pintores) e aos rituais celebrados, inclusive os músicos. Os leigos, membros da irmandade, administravam a organização eclesiástica, já que havia poucos padres para ministrar cultos em todas as Igrejas. Os padres eram pagos pelas irmandades mas não pertenciam às suas Igrejas, as quais, portanto, não eram paróquias.

\section{Festas Maiores e Menores}

As atividades dos músicos estavam em grande parte conectadas à Igreja (clérigos, Irmandades e Confrarias) e seu calendário litúrgico (festas maiores e menores), assim como aos eventos públicos. Eventos seculares relacionados ao entretenimento 
privado, como saraus e bailes, certamente existiram, mas a documentação é praticamente inexistente. A organização das festas maiores era legislada pelos governadores das capitanias, os quais estavam subordinados ao Conselho Ultramarino e este ao rei de Portugal. Aspectos relacionados diretamente com os rituais religiosos eram regulamentados pelo Bispado local. O Senado da Câmara estabelecia o contrato e provia suporte financeiro às atividades musicais nas Igrejas referentes às festas maiores. A seleção da corporação de músicos encarregada, todo o ano, das festividades oficiais regulares era realizada por dispositivo democrático, a arrematação pública. Conforme Lange (1966: 6870), tal dispositivo consistia numa ação pública sob responsabilidade do Senado da Câmara e era aberto a todo e qualquer músico profissional. Era realizada na praça principal da vila, geralmente todo dia 31 de dezembro. A ação selecionava o melhor serviço e preço, estabelecendo um contrato anual com a corporação de músicos ou cantoria, um grupo de músicos reunido em torno de um líder ou mestre, o qual geralmente acumulava a função de regente, compositor e executante. O contrato estabelecia também um fiador, o qual substituiria o "arrematante" em caso de doença ou algum tipo de impedimento. O contrato para a música de festividades eventuais era feito caso por caso.

As festividades menores eram organizadas e financiadas pelas irmandades, pois geralmente se referiam à celebração de dias de padroeiros e padroeiras. As irmandades tinham também seu calendário litúrgico e paralitúrgico, que demandava gêneros musicais como Missa, Missa de Requiem, Novena, Setenário, Ladainha, Antífona, Te Deum, Invitatório, Jaculatórias, Responsório, Matinas, Moteto, Hino, Ofertório, Responsórios Fúnebres, Salmo, Oficios de Semana Santa, Stabat Mater e Gradual. A documentação musical descoberta até o momento pertence ao período de decadência da mineração nas Minas Gerais ${ }^{6}$. As irmandades tendiam a estabelecer contratos com seus próprios membros. Em alguns casos, o irmão trocava o pagamento de sua anuidade por serviço como músico. No entanto, tudo indica que, 
na maior parte dos casos, sua posição como músico profissional era independente de sua filiação à irmandade; a anuidade do músico enquanto membro e o pagamento por parte da irmandade para profissionais eram feitos independentemente. $\mathrm{O}$ contrato com o mestre músico era feito "uma só vez, renovando-se este automaticamente quando não existisse queixa de uma das partes contratantes" (LANGE, 1966: 68). Não há evidência de que as irmandades, antes do aparecimento da Irmandade de Santa Cecília em 1815, operassem como sindicato. Embora irmandades tendessem a reunir pessoas que trabalhavam na mesma área, provavelmente por amizade ou camaradagem, nada consta em seus estatutos concernente à regulamentação ou proteção de interesses como categorias profissionais. Conforme Lange (1966: 63), "para isso existiam, separadamente, as corporações de oficios". A Irmandade de Santa Cecília foi a única que, além das funções normalmente atribuídas a qualquer irmandade, operou também como sindicato. Entretanto, em Minas Gerais, ela foi estabelecida apenas no início do século XIX; 1815 em Vila Rica; 1817 em Sabará e 1818 em Mariana $^{7}$. Em Minas Gerais a Irmandade de Santa Cecília atendeu à necessidade de maior controle das atividades musicais no período de decadência da mineração do ouro, quando recursos financeiros para eventos musicais tornaram-se cada vez mais escassos. É assunto ainda controvertido se o período de apogeu musical em Minas Gerais (1750-90) foi regulamentado pela Irmandade Santa Cecília. A única evidência referente à existência desta irmandade antes do século XIX é o compromisso enviado ao Príncipe Regente Dom João, pelos "professores da Arte da Música", na ocasião de sua fundação, e que diz que "eles há anos têm se congregado em uma Confraria tomando por sua Protetora a Gloriosa Santa Cecília colocando, entretanto, que não podem fazer uma capela própria em um dos Altares da Igreja do Ouro Preto, em cujo lugar costumam festejar o aniversário da mesma Santa" (LANGE, 1966: 65).

Há forte evidência de freqüentes oportunidades de emprego para os músicos. O calendário católico previa dias santos todos os meses. O ano eclesiástico católico é dividido em dois grupos: 
1) as festividades relacionadas aos episódios da vida de Jesus: Natal, Semana Santa, incluindo música para o Domingo de Ramos ou Procissão de Passos, Quarta-feira Santa, Quinta-feira Santa, Sexta-feira Santa, Sábado Santo e Domingo de Páscoa; Pentecostes, Santíssima Trindade, e Corpus Christi; e 2) os dias de santos. Dias dedicados a santos padroeiros das irmandades existentes em Minas Gerais preenchiam praticamente todos os meses, dos quais podemos citar, entre outros, N. Sra. do Pilar (2 de janeiro), São Sebastião (20 de janeiro), São Gonçalo (5 de fevereiro), São José (19 de março), São Francisco de Paula (2 de abril), São Benedito (4 de abril), todo o mês de Maio dedicado a Maria, com festividade especial no dia 24, Santo Antônio (13 de junho), São João Batista (24 de junho), São Pedro (29 de junho), N. Sra. do Monte Carmelo (16 de julho), N. Sra. Santana (26 de julho), N. Sra. da Assunção (15 de agosto), N. Sra. das Dores (15 de setembro), N. Sra. da Piedade (15 de setembro), Santa Efigênia (21 de setembro), N. Sra. das Mercês (24 de setembro), São Miguel e Almas (29 de setembro), São Francisco de Assis (4 de outubro), N. Sra. do Rosário (7 de outubro), N. Sra. do Terço (7 de outubro), Santa Cecília (22 de novembro), N. Sra. da Conceição (8 de dezembro), N. Sra. da Expectação do Ó (18 de dezembro).

As festas maiores e menores celebradas de acordo com um calendário regular construíram, através da repetição cíclica, um sentido de estabilidade numa sociedade perturbada por interesses conflitantes entre os diversos segmentos da população, e entre estes e a Corôa. Entretanto, é um equívoco considerar que tais festividades eram apenas um instrumento de manipulação e controle social. As festividades cíclicas eram "carregadas de simbolismo" (para discussão desse conceito, ver TURNER, 1967 e TURNER, 1969: 52-3), expressando a relação de forças e a dinâmica da negociação entre o forte e o fraco, as expectativas de mudanças e que aliviavam as tensões sociais. Salles (1963: 95-110) analisa polêmicas canônico-judiciais entre irmandades como reflexo de sua representatividade dos diversos segmentos da sociedade com interesses conflitantes. "Tais pleitos, não raro, assumiam caráter 
de inegável agressividade de uma corporação contra a outra, culminando, todos, no desfecho judiciário. Muitas, entre as batalhas jurídico-canônicas, duraram dezenas de anos e terminaram pelo extermínio da irmandade derrotada." No que tange à etnicidade, a fase mais aguda desses processos ocorreu por volta da década de 1770 , quando os mulatos adquiriram força como grupo social. O conflito entre a Arquiconfraria dos Mínimos do Cordão de São Francisco (mulatos) e a Ordem Terceira de São Francisco (brancos), em Mariana, ilustra como o simbolismo dos rituais era pleno de sentido. A irmandade de brancos argumentou sobre a legitimidade de a irmandade de mulatos usar a insígnia de São Francisco nas procissões e qualificou tal fato de um "escândalo", "usurpação de posse", "desaforo grande", "abuso", e assim por diante. A Ordem Terceira de São Francisco alegou toda sorte de argumentos, desde problemas relacionados à iniciação do "corpo de noviciado de mulatos" até a reputação moral das "pardas meretrizes". O poder representativo da irmandade de mulatos se faz evidente justamente no fato de que o primeiro veredito foi favorável ao Cordão de São Francisco e o processo durou 15 anos. Esta contenda sobre manipulação adequada e uso de objetos simbólicos em ritual envolve problemas étnico-econômicos e provavelmente conflitos políticos, se é que o Cordão de São Francisco estava de fato envolvido em assuntos políticos.

Outro exemplo dado por Salles ilustra a competição de prestígio social entre irmandades do mesmo estrato social. A Ordem Terceira de São Francisco e a Ordem Terceira do Carmo, em Vila Rica, disputaram durante 30 anos a precedência em procissões e enterros. De acordo com o texto canônico, a seqüência seguia a hierarquia entre as irmandades, ou seja, Ordens Terceiras, Arquiconfrarias, Confrarias e Irmandades, e Pias Uniões. Na procissão do Santíssimo Sacramento, a confraria sob tal nome precede às arquiconfrarias (SALLES, 1963: 18). A existência de duas Ordens Terceiras tornou a decisão de quem vai primeiro menos óbvia e acabou sendo um motivo de rivalidade entre duas correntes pertencentes à classe dirigente, "cada uma delas a se considerar 
o organismo social de cúpula da sociedade e, portanto, superior à outra" (SALLES, 1963: 106). Este autor assinala também que nada indica que tal disputa tivesse motivações de diferenciação de conteúdo social; e entre guerra e paz, "novamente se destaca a identidade de conteúdo de ambas" (SALLES, 1963: 106-8).

Eventos religiosos descritos e analisados por Carrato (1968: 76-82) mostram como a divergência de ideologia ou poder secular e religioso se expressavam em muitos rituais através do comportamento simbólico. Carrato (1968: 80-1) narra um evento no qual a música foi usada diretamente como instrumento simbólico de disputa entre autoridades política e religiosa. Em Arraial do Tejuco (Diamantina), o dia de Santo Antônio era geralmente celebrado com procissão. Em 1799, o promotor da festa, o Intendente João Inácio do Amaral Silveira, substituiu a procissão por um concerto musical realizado dentro da Igreja Matriz, onde o Santíssimo Sacramento estava exposto. Tal concerto de música secular para celebrar um feriado religioso foi atendido pelo intendente e seus amigos. Músicos profissionais e competente cravista amador tocaram "uma Orquestra de Sinfonias, quartetos, e outras musicas profanas de Plieal [com certeza, o compositor austríaco Ignaz Pleyel, então em plena voga na Europa, o que prova como os músicos mineiros estavam atualizados!] et coetera com que assentados de perna cruzada se divertiram toda a tarde, causando este fato escândalo grande nesta povoação" ("Requerimento do Povo", in Revista do Arquivo Público Mineiro, II, p. 173, apud CARRATO, 1968: 80-1). Tal comportamento simbólico é analisado por Carrato como expressão da "mentalidade regalista das autoridades coloniais que usavam a Igreja como casa sua e os padres como seus lacaios" (1968: 78), subestimando a autoridade eclesiástica. Subverter convenções rituais foi uma forma de enunciar quem tinha poder e quem fazia as regras, neste caso, a hegemonia do temporalis sobre o spiritualis. Conforme Carrato (1968: cap. II. 3 "As elites na Igreja Mineira", pp. 73-95), esta atitude envolvia também o espírito pombalino, o sentimento anticlerical impregnado de idéias voltaireanas, e simpatia para com 
o espírito liberal da Revolução Francesa. O catolicismo era usado como instrumento legitimador do poder monárquico e seus rituais expressavam a parceria Igreja-Estado, a qual não era no entanto inteiramente sem conflitos. Rituais católicos se tornaram o melhor alvo para asserções simbólicas de hegemonia do poder temporal e também de ideologias anti-religiosas, liberais e até mesmo antimonárquicas.

\section{O Triunfo Eucarístico}

O período de 130 anos de mineração em Minas Gerais viu quatro enormes festividades, as quais refletem o processo de desenvolvimento daquela sociedade: o Triunfo Eucarístico (Vila Rica, 1733), o Áureo Trono Episcopal (Mariana, 1748), as Núpcias do Príncipe Dom João (Vila Rica e Sabará, 1786) e a Coroação de Dom João VI (Vila Rica e Sabará, 1817). A maior parte dos documentos que descrevem tais festividades consiste de relatórios administrativos ou crônicas escritas na maior parte por europeus que assistiram a tais eventos. O Triunfo Eucarístico, uma das festividades mais suntuosas em Minas Gerais durante os tempos coloniais, celebrou o traslado do Divino Sacramento da Igreja de Nossa Senhora do Rosário para a nova Igreja Matriz de Nossa Senhora do Pilar. Toda a festividade durou aproximadamente dois meses e foi meticulosamente descrita por Simão Ferreira Machado na obra literária homônima, publicada em Lisboa em 1734. Este documento tem sido tratado como documento histórico, porém com certa precaução, pois o estilo literário que caracteriza a narrativa dos fatos pode conter alguns exageros ou improbabilidade. Entretanto, alguns estudiosos têm rejeitado ou minimizado tal restrição, pois outras evidências têm mostrado que muitas outras celebrações foram tão fabulosas quanto a descrita no Triunfo Eucarístico. Além disso, estudos que abordam o Triunfo Eucarístico como gênero literário, sob a perspectiva de sua retórica e recursos poéticos barrocos, têm mostrado que a linguagem figurativa não deturpa a realidade mas a interpreta através da visão de mundo do 
século XVIII, a que a própria obra e evento pertencem. Em outras palavras, tal gênero literário é, na verdade, uma interpretação coetânea (entre muitas, uma vez que não se pode negar o problema da representatividade do autor ${ }^{8}$ cuja figura de linguagem e metáforas foram construídas no seu próprio sistema simbólico.

Affonso Ávilla escreveu os estudos mais marcantes sobre gêneros literários do Período Colonial, como os Sermões do Padre Antônio Vieira, as Cartas Chilenas de Tomás Antônio Gonzaga, o Triunfo Eucarístico, o Áureo Trono Episcopal e os chamados "sermões mineiros", como por exemplo, o sermão à morte do Rei de Portugal D. João V, do Padre Matias Antônio Salgado. Ávilla (1971:12) propõe uma interpretação totalizadora dos múltiplos aspectos que coordenam histórica e esteticamente o fenômeno barroco, particularmente na sua manifestação brasileira. A linha interpretativa proposta por esse autor privilegia três categorias expressivas: o lúdico, a ênfase visual e o persuasório (ÁVILLA, 1971: 22). Ávilla caracteriza o "impulso lúdico" da estética e atitude barrocas como "tendência à ruptura ou suspensão da ordem séria da vida e da rotina orgânica da natureza" (1971: 23). O conceito de jogo não é o jogo-entretenimento, o jogo-comprazimento ou o jogo-competitivo, mas o jogo simbólico ou criativo (1971: 26). "Huizinga" pretende mesmo ver o jogo nos mitos, nos rituais, nas práticas coletivas, convertido numa forma de vida, plena de sentido e função, que deve ser considerado em seus múltiplos aspectos "como uma estrutura social" (ÁVILLA, 1980: 26). Esta idéia de jogo simbólico pode ser relacionada com o conceito de símbolos rituais de Turner e suas "propriedades de condensação, unificação de elementos disparatados e polarização de significado" (TURNER, 1969: 52), cuja importância varia em contextos diferentes (TURNER, 1969: 53).

O jogo simbólico que caracteriza o Triunfo Eucarístico envolve a criação de um espaço não-ordinário, dramatização e persuasão. $\mathrm{O}$ aspecto persuasivo da estética barroca tem sido amplamente discutido em termo de sua forma verbal (retórica) e espaço-visual (arquitetura, pintura, escultura). Tais formas, mais 
música e dança, mímica e drama estavam todas presentes no Triunfo Eucarístico de 1733. A retórica esteve presente no sermão, nas mensagens distribuídas pelos pagens e na dramatização de alguns personagens da procissão. $\mathrm{O}$ espaço-visual dominou no modo como foram combinadas a topografia da cidade e sua ornamentação, particularmente as luminárias, e também os prédios, em especial a Igreja do Rosário e a Igreja Matriz do Pilar, e o uso do espaço público. A pintura esteve presente em muitos elementos da procissão, como nas bandeiras e carruagens, além do uso global de cores e materiais reluzentes. A escultura esteve, obviamente, presente nas imagens de santos carregados na procissão, cuja função não era decorativa mas carregada de significado baseado no sistema simbólico da hagiologia católica romana oficial e popular. O impacto visual, constituído como jogo simbólico, foi um dos mais importantes instrumentos de persuasão e de criação de um espaço não-ordinário.

Este espaço não-ordinário foi percebido como "espaço celestial" e concebido de acordo com o sistema religioso católico, no qual a dicotomia céu e inferno, Deus e diabo, enfatiza a expectativa na vida eterna (post mortem) mais do que na transitória vida terrestre. Tal espaço não-ordinário, funcionando como local ritual trouxe "o paraíso para a terra", fazendo a ponte entre os domínios sagrado e secular. A comunicação com o sobrenatural estabelece reciprocidade entre homem e Deus, e a promessa de vida eterna no paraíso está diretamente relacionada com a demonstração de fé, adoração e comportamento adequado. A religião implica obrigações e direitos, e o modo como o catolicismo português cumpriu seus deveres de adoração foi muito exteriorizado. "Sua religião, pois, é culto, antes de tudo, é exteriorização, é a prática devocional externa (...) Assim, não será o dogma, o ato puro da fé, fruto da razão e do assentimento racional, que obrigará o culto conseqüente (...). Não, é o culto, através do símbolo, da manifestação sensível, que levará àquele [ao dogma] (...). A Eucaristia - esse dogma belíssimo do Santíssimo Sacramento do altar - será muito mais entendida e sentida pelos préstitos 
monumentais de Corpus-Christi do que pelo ensinamento dogmático, hermético no mistério" (CARRATO, 1968: 31-2).

Toda a festividade descrita no Triunfo Eucarístico (Corpus Christi) é cheia de gestos simbólicos, símbolos rituais e figuras alegóricas, desde o bando de máscaras (de fins de abril até 3 de maio) anunciando o evento por vir (programado para durar de 23 a 25 de maio, mas por causa do mau tempo, foi até 26 de maio) até os eventos finais (de 27 de maio até 5 de junho), e sobretudo a procissão realizada em 24 de maio. $O$ presente artigo não relata tal festividade, a qual é disponível em edições modernas ${ }^{10}$. No entanto, é necessário apresentar uma seleção sistematizada de dados considerados relevantes para o estudo daquele evento sob a perspectiva dos estudos rituais. Embora extremamente detalhada, algumas descrições oferecidas pela obra de Machado são incompletas do ponto de vista etnográfico. O sumário abaixo reproduz, portanto, a maior quantidade de dados disponíveis nesta fonte, complementando com informações que ofereçam maior contextualização do sentido associado aos elementos que fazem parte do jogo simbólico. Também foram incluídas neste sumário algumas considerações analíticas que irão embasar a análise exposta após este sumário.

\section{As Festividades do Triunfo Eucarístico 1733: Sumário Cronológico-Descritivo-Analítico}

- Desde fins de abril até 3 de maio (domingo): Divulgação: a solenidade foi anunciada ao povo por máscaras. Jogo simbólico enfatiza estímulo sensorial de impacto visual, percebido como "aprazível objeto da vista", e em gestos simbólicos como "jocosidade", "galanteria" e "por diferentes modos".

- 3 maio (domingo): veneração pública das duas bandeiras de damasco (tecido de seda com desenhos lavrados) de cor carmesim: uma, com N.Sra. do Rosario numa face e a custódia do Sacramento na outra; a segunda bandeira com N.Sra. do Pilar numa face e a custódia do Sacramento na outra, passando pelas ruas da vila 
carregadas duas pessoas ricamente vestidas. Finalmente, colocadas cada uma defronte ao respectivo templo. Grande assistência pública. - Dia da Ascensão "1: o Reverendo Vigário da Vara de Vila Rica, Félix Simões de Paiva, benze a nova igreja. Este evento consiste num ritual mágico, onde um objeto é sacralizado; a nova igreja não pode funcionar como templo religioso antes de ser limpa das forças do mal e impregnada pelo poder divino. Benzer a nova igreja é, portanto, um ritual de passagem, uma vez que há mudança de estado, de ordinário para sagrado; depois da benção, o prédio da igreja torna-se um espaço sagrado, a casa de Deus. Assistência: todo o clero de ambas as paróquias, vários religiosos e a maior parte do povo da vila e arredores. Danças e máscaras de dia; música à noite.

- desde o dia da Ascensão até o dia do Traslado (24 de maio): Danças e máscaras de dia; música à noite. Tais eventos foram extralitúrgicos, ou seja, ocorreram fora de contextos litúrgicos ou paralitúrgicos, indicando, portanto, que as músicas tocadas à noite consistiram de gêneros seculares.

- de 17 (domingo) até 22 de maio (sexta-feira): seis dias consecutivos antes do Traslado: luminárias entre os moradores de Ouro Preto (por ordem do Senado). Velas do lado de fora de todas as casas reluzindo à noite toda causaram impacto especial naquela paisagem de topografia em colinas. Luminárias criaram um espaço não-ordinário, transformando a cidade num corpo celestial. Este espaço não-ordinário constituiu, no entanto, uma situação paradoxal, pois não suspendeu a diferenciação social, mas continha estrutura e "commmintas normativa" superpostas, como indicam dois aspectos descritos por Machado. Um, concernente à ordem do Senado para que as casas de Ouro Preto acendessem velas por seis dias consecutivos, três dos quais deveriam ser gerais, ou seja, toda a vila. A permissão de incluir o bairro de Padre Faria como parte do corpo celestial, considerado então "idôneo para dilatar às luzes o domínio das trevas", envolve um conflito entre autoridades políticas e a população daquela vizinhança, composta sobretudo por negros e mulatos. Outra diferenciação estrutural concerne ao 
morro Pascoal da Silva, onde moravam os ricos e nobres. A declaração: "no altíssimo morro ... as luzes ... mostravam aos juízes o centro da opulência", mostra que havia espaço para afirmação de poder pela classe dominante neste espaço não-ordinário. Além disso, a interpretação de Machado de que as casas do morro Pascoal Silva, "por sua altura, na região das nuvens pareciam aos olhos luminárias do céu", mostra que as luminárias, enquanto espaço nãoordinário, praticamente sacralizaram o poder da classe dominante. A relação de poder é legitimada também pela reação das forças naturais e pelo "juízo comunicado do Céu": "a claridade dos ares, [e] a serenidade do tempo" eram sinal de que Deus comunicava através da natureza a sua concordância com a ordem temporal dos homens. O consentimento com a ordem social se expressa também na "ordem da multidão". O jogo simbólico de persuasão opera através de estímulos visuais e sonoros ("estrondosa harmonia dos sinos, melodia artificiosa das músicas"), ação corporal simbólica ("estrépito das danças"), símbolos visuais ("adorno das figuras") e recurso barroco da varietas ("formosura da variedade"). O efeito persuasivo é enunciado por Machado como "influirão nos corações o sentimento de júbilo de tão suave alegria".

- 23 maio (sábado, à tarde) [4 sábado do mês]: estava programado para a "solene pompa do Traslado"; estava tudo pronto, todos ali, o tempo fora sereno desde que amanhecera mas na hora da procissão, choveu repentinamente. Houve um discurso persuadindo que o impedimento foi providência divina, "de superior mistério" porque o dia seguinte era dia da Mãe de Deus: o próprio Senhor cedeu à sua mãe a apropriada glória que deveria ser honrada no seu dia. A chuva foi "a muda voz do Céu, antecipada expressão de agrado com que via em competência a fé nos entendimentos, nas vontades do amor" ou, em outras palavras, sinal divino de aprovação à concórdia entre os grupos étnico-sociais. Esta é a interpretação da classe dominante. No entanto, Araújo (1964, v. I: 101-1) menciona que desde os tempos da escravatura, negros e crianças costumavam sair em primeiro lugar nas procissões, e que havia um tabu popular de acordo com o qual nenhuma procissão 
deveria sair sem a imagem de São Benedito ou sua irmandade em primeiro lugar, pois o santo negro castigaria tal desdém trazendo chuva. "Nenhuma procissão sai sem que à frente esteja o santo negro. Senão, é chuva na certa". São Benedito é caso típico da religiosidade popular brasileira, uma cristandade de tendência antropomórfica que transfere características humanas aos santos, à Virgem e a Jesus, até mesmo fraquezas; neste caso, a vingança. A procissão do Triunfo Eucarístico de 1733 não abriu com São Benedito, nem na primeira nem na segunda seção, a não ser que o santo negro abrisse a segunda seção da procissão onde "varias Irmandades guiadas por suas cruzes de prata... conduzissem os seus Santos padroeiros". Tal possibilidade não parece muito plausível pois a imagem de São Benedito aparece mais tarde na procissão com a Irmandade de N. Sra. do Rosário dos Pretos. Devido à chuva inesperada, a procissão foi adiada para a manhã seguinte.

- 24 maio (domingo, manhã): ocorreu o Traslado do Divino Sacramento. Janelas das casas enfeitadas com sedas e damascos nas ruas destinadas à procissão expressam sentimentos e crenças religiosas compartilhadas pela população da vila. Havia cinco arcos ornando as ruas ("triunfo de ouro e diamantes"); num deles "um altar para o descanso do Divino Sacramento", o que propiciou o ato de veneração pública. Jogo simbólico do cenário, enfatizando estímulo sensorial de impacto visual interpretado por Machado como "uma vária e agradável perspectiva para a vista, empenhada competência de preciosidade e artificio", além da ambiência natural de verde dos campos, flores da primavera, aromas da Arábia do Oriente e raios de sol de luzes douradas e prateadas. Persuasão é efetuada pela criação de espaço não-ordinário, que tende a êxtase sensorial e "delícia".

- Antes de sair a procissão, foi feito um gesto simbólico pelo qual o Divino Sacramento foi colocado no braço de Nossa Senhora em lugar do menino Jesus. Em seguida teve lugar um ato litúrgico: uma missa oficiada a dois coros de música foi celebrada pelo Reverendo Doutor José de Andrade e Moraes, o qual pronunciou 
um sermão como último ato desta solenidade dentro da Igreja do Rosário. Tais eventos foram atendidos pelos nobre e militares em gestos galantes e solenes, e pelo povo em geral. Depois desta solenidade dentro da igreja do Rosário, foi realizada a transferência do Divino Sacramento, a qual consistiu de procissão monumental, desde esta igreja até a nova Matriz de N. Sra. do Pilar.

\section{- Procissão:}

Seção I:

I. Dança de Turcos e Cristãos: 32 figuras militarmente vestidas, divididas em dois grupos, cada um tinha um Imperador e quinze Alferes $^{12}$. Eles conduzem dois carros com excelente pintura e dentro vão os músicos de suaves vozes e vários instrumentos (não há indicação sobre o tipo de música executada). A dança representa o tema da conversão, consistindo numa encenação simbólica de um ritual transformador, de acordo com a definição de Turner (1969).

II. Dança dos Romeiros: gravidade do gesto, variedade da ordem, diferentes mudanças de arte (opera o princípio barroco da varietas).

III. Dança dos músicos: dois carros de madeira com pintura singular: o menor com uma serpente e o maior com uma abóbada onde um cavaleiro escondido aparecia de repente, montado à cabeça da serpente, encenando ("tudo representação") "a história humana, ou da Escritura em termos breves e claros". A serpente contém dois significados simbólicos, um relativo à mitologia católica da tentação e pecado capital; e o outro formado localmente como perigo constante naquela região, ilustrado pelo relato enviado a Lisboa em 1735, que diz"a passagem para as Minas Novas, desde os Currais da Bahia para baixo, é extremamente perigosa neste rio [Jequitinhonha], em respeito às cobras que têm em si chamadas sucuriúbas. Estas são algumas de vinte varas de medir, e grossas quase como um homem e comem os negros que apanham em tais paragens e lançam gados e cavalos e tudo o mais que vai à beira daquele rio. E na passagem deste rio para as Minas Novas andava 
uma que tinha feito muito estrago. Foi morta por um ermitão de São Gonçalo de Sabará, como por milagre do mesmo Santo, vemos colocado em sua capela." (LIMA JÚNIOR, 1965: 110-1).

IV. Quatro figuras a cavalo representando os Quatro Ventos, Norte, Sul, Leste e Oeste, "vestidos à trágica" e com plumas brancas, ouro e diamantes.

- O Vento Oeste montava um cavalo castanho escuro mosqueado de branco, com sela de veludo cor de ouro, e sua vestimenta tinha como cores diferenciais o verde, rosa, branco e prata; tinha também duas asas, uma inscrição nas costas com seu nome e carregava uma trombeta na mão esquerda.

- O Vento Sul montava um cavalo castanho, de sela verde bordada em ouro, e sua vestimenta tinha como cores diferenciais o azul e branco. - Os Ventos Norte e Leste vestiam "as cores que the competiam". "Depois vinham as figuras mais majestosas de toda a procissão; todas a cavalo vestidas à trágica".

V. A figura da Fama (divindade alegórica representada por mulher tocando trombeta", conf. ÁVILLA, 1967, vol. I: 289), vestida com plumas brancas, diamantes e ouro, montada num cavalo russo pedrez e segurava haste de prata rematada em cruz com estandarte de tela branca; numa face, pintada a arca do testamento e na outra, a custódia sobre um letreiro: Eucharistia in trasladatione vitrix ("A Eucaristia, vitoriosa na translação", conf. ÁVILLA, 1967, vol. I: 289).

- Seguiam dois pagens que proferiam elegantes poemas da Fama em elogio à solenidade.

VI. A figura de Ouro Preto, representando a vizinhança da nova Matriz, para onde a procissão se dirigia.

- Tal figura foi precedida pelo "Alemão"13 os "negros choromeleiros"14 e o pagem principal da figura. O "Alemão" tocava clarim, estava vestido "à castelhana", em veludo roxo bordado de ouro com diamantes e plumas coloridas, montado num cavalo russo de sela de veludo carmesim bordada em ouro. Os "negros choromeleiros" caminhavam atrás. As "vozes" do clarim alternavam com as "vozes" das choromelas. A figura de 
Ouro Preto vinha montada no melhor cavalo desta seção, russo, sela de veludo verde bordada em ouro, ferragem toda de prata, crinas bordadas com diamantes. Sua vestimenta era de ouro, diamantes e plumas. Na parte frontal da vestimenta estavam bordadas as Armas Reais sobre a inscrição "Viva Ouro Preto". Esta figura segurava na mão direita uma pequena bandeja cheia de diamantes, significando Ouro Preto.

- Seguiam as figuras de Ouro Fino e Ouro Preto, simbolizando os dois "morros entre os quais está fundada a Vila".

- Seguiam dois pagens vestidos à trágica.

VII. As figuras dos Sete Planetas:

1. Lua (vestimenta composta de diamantes, cor azul, prata, pérolas, plumas brancas, seda, detalhes em ouro, turbante azul com lua cheia no topo) carregando um arco no braço e uma flecha na mão, montada num cavalo branco.

- Precedida de duas ninfas (cada uma com um cão perdigueiro em coleira de prata em forma de cascavel) e dois pagens.

2. Marte (vestimenta composta de branco, diamantes, prata e ouro) montado num cavalo russo rosado.

- Precedido por três figuras vestidas de Mouros (com plumas carmesim, verde, prata e branco): a figura do meio tocava uma caixa de guerra, a da direita, um pífaro e a da esquerda, uma trombeta. Seguido de dois pagens (carmesim, verde, azul, ouro, prata) segurando duas escopetas de lavores de prata.

3. Mercúrio $^{15}$ (de cabeleira branca, vestimenta composta de vermelho, azul, rosa, amarelo, prata, ouro e diamantes) montado num cavalo russo, segurando na mão direita um caduceu ${ }^{16}$ dourado.

- Precedido por duas figuras tocando clarim;

- Escoltado por dois pagens.

4. Sol: o rei (cabeleira de fios de ouro, vestimenta composta de ouro, diamantes e cores de fogo) montado num cavalo castanho vestido como um unicórnio. Esta era a figura mais majestosa desta seção.

- Precedido por duas figuras: a estrela d'alva (nas costas vinha o nome "Lúcifer"17 e a estrela da tarde. Ambas de vestimenta compostas de branco e prata. 
- Escoltada por seis pagens, três de cada lado, os quais eram garotos mulatos com barretes à mourisca na cabeça (verde, plumas brancas).

5. Júpiter (vestimenta composta de plumas azuis e brancas, diamantes, ouro e prata), segurando um cetro de ouro na mão direita e um escudo dourado com sua insígnia no braço esquerdo, vinha num carro triunfante (coberto de seda nácar guarnecido de galões de prata; nas rodas anteriores estava pintado o signo "sicsip" e nas rodas posteriores o signo "sagittario"; puxavam duas águias coroadas de ouro.

- Rodeado por dois pagens representando os satélites.

6. Vênus (vestida em verde e rosa, pérolas, ouro, diamantes e pedras preciosas), com expressões faciais de formosura e compostura; trazia no braço esquerdo um escudo com uma pintura de um coração abrasado em fogo e um ramalhete de flores na mão direita, e vinha num carro triunfante em feitio de concha.

- Rodeada por dois pagens representando dois cupidos (verde e rosa), com arcos e setas.

7. Saturno: velho homem com aspecto fúnebre e influências lúgubres, cabelo e barba natural (vestimenta composta de plumas azuis e brancas, diamantes e ouro), montado num cavalo castanho de sela verde bordada em prata, segurando um pequeno escudo com sua insígnia no braço esquerdo e uma foice de prata na mão direita.

- Precedido por duas estrelas vestidas como soldados romanos, cada uma com uma meia lança nas mãos.

"Todas estas majestosas figuras dos Planetas pela memória da Divindade que neles adorava o fingimento da antiga Idolatria, eram glorioso triunfo do Eucarístico Sacramento: que como no feliz século da Redenção humana foi alcançado pelo mesmo Senhor Sacramentado; se via agora na memória, e figura renovado para estímulo da pública veneração da Cristandade, e maior glória do mesmo Senhor" (Revista do Arquivo Público Mineiro, VI, p. 1009).

VIII. Figura da nova Igreja Matriz vinha em formosíssimo cavalo branco. Em vestimenta composta de azul e branco, 
diamantes, ouro, plumas brancas e pedras preciosas, a mais soberba de todas as figuras "punha fim a toda esta ordem de figuras". Segurava no braço esquerdo um escudo de ouro com uma pintura da Igreja matriz sobre a inscrição Haec est domus Domini firmiter aedificato ("Esta é a casa do Senhor, firmemente edificada", cf. Ávilla, 1967, vol. I: 290), e na mão direita um estandarte de tela branca pintado em uma face a N. Sra. do Pilar com a inscrição Ego dilecto meo ("Eu para o meu amado",cf. Ávilla, 1967, vol. I: 289) e na outra face a custódia da Eucaristia com a inscrição Et ad me conversio ejus ("E para mim as atenções dele", cf. Ávilla, 1967, vol. I: 289).

- Rodeada por dois pagens de cada lado (vestimenta em azul e branco) levando nas mãos "as insígnias da figura que acompanhavam".

Seção II:

I. Várias irmandades levando a imagem de seus respectivos santos padroeiros guiadas por suas cruzes de prata; todos em gesto grave adequado ao solene ato.

- Precedidas por um gaiteiro vestido à castelhana e um "moleque" tocando tambor.

II. Quatro negros montados em cavalos brancos e tocando trombetas donde pendiam estandartes de seda branca com a custódia pintada.

III. O guião da Irmandade do Santíssimo Sacramento (de damasco carmesim franjado de ouro com a custódia bordada) era levado por um irmão vestido de custosa gala, e outros dois irmãos iam ao lado levando duas tochas.

IV. Irmandade dos Pardos da Capela do Senhor S. José, levando o andor da imagem de $\mathrm{S}$. José (grande número de irmãos).

V. Irmandade Nossa Senhora do Rosário dos Pretos: três andores levando as imagens de Santo Antônio Calatagirona, S. Benedicto e N. Sra. do Rosário (grande número de irmãos).

VI. Irmandade S. Antônio de Lisboa: três andores levando as imagens de S. Antônio, S. Vicente Ferreira e S. Gonçalo do Amarante (grande número de irmãos). 
VII. Nobres que serviram a República do Senado da Câmara, quatro dos quais levando o andor da imagem do santo padroeiro do Senado da Câmara, o mártir S. Sebastião (grande número de irmãos).

VIII. Irmandade Nossa Senhora do Rosário do Terço dos Brancos: andor levando a imagem de sua santa padroeira (grande número de irmãos).

IX. Irmandade Nossa Senhora da Conceição: andor levando a imagem de sua santa padroeira (grande número de irmãos).

$X$. Irmandade Nossa Senhora do Pilar: andor levando a imagem de sua santa padroeira (grande número de irmãos).

XI. Irmandade do Santíssimo Sacramento (grande número de irmãos); o Provedor desta irmandade teve a honra de levar a vara de prata; um sacerdote levava a cruz; o clérigo numeroso de ambas as paróquias (Antônio Dias e Pilar) e suas anexas levavam velas de livra; quatro sacerdotes levavam a imagem do Patriarca S. Pedro rodeado por oito sacerdotes de cada lado revestidos de ricas casulas, manípulos e estolas, seguidos por mais oito sacerdotes com dalmáticas, seguidos por mais oito sacerdotes vestidos com capas de asperge, seguidos por mais quatro sacerdotes segurando turíbulos; seguidos por um sacerdote que carregava o pedestal para descanso da custódia em que ia o Divino Sacramento; quatro anjos vestidos à trágica levando bandejas cheias de flores que iam lançando pelas ruas; o Divino e Eucarístico Sacramento veio nas mãos do Reverendo Vigário da Matriz, revestido com rica alva, estola, capa de asperge, e véu de ombros; vinham mais dois sacerdotes vestidos de ricas alvas e dalmáticas de tela branca.

XII. O governador de Minas Gerais, Conde de Galveas.

XIII. Todos os militares e nobreza literária da vila e outras partes.

XIV. O nobre Senado da Câmara.

$\mathrm{XV}$. Companhia dos Dragões que deram três cargas de mosquetaria depois de recolhida a procissão.

A última parte do evento da manhã no dia do Traslado foi dentro da Igreja Matriz, onde o Divino Sacramento foi colocado e 
exposto em um Trono. $\mathrm{O}$ ato litúrgico que encerrou este dia foi a celebração de uma "Missa cantada com música a dous coros: pregou ao Evangelho o Dr. Manoel Freire Batalha; e de tarde fez o mesmo do Conde Governador, de toda a Nobreza e Senado da Camera" (Revista do Arquivo Público Mineiro, VI, p. 1013).

O Dia do Traslado mais os dois dias seguintes formavam o Tríduo (24, 25326 de maio), que consistia de uma série de atos litúrgicos e paralitúrgicos.

No dia 25 de maio (segunda-feira de manhã) houve Missa cantada a dois coros e Evangelho. No mesmo dia à tarde, proferiu o Dr. José Andrade e Morais. Ambos os eventos foram atendidos pelo Conde Governador, de toda a Nobreza e Senado da Câmara e povo em geral.

No dia 26 de maio (terça-feira) houve Missa cantada a dois coros, houve sermão de manhã, e de tarde pelo Reverendo Padre Diogo Soares da Companhia de Jesus. A assistência compreendia o Conde Governador, de toda a Nobreza e Senado da Câmara e povo em geral.

No dia 27 de maio (quarta-feira à noite) ardeu um "artificioso fogo feito num plano perto da Igreja Matriz, fabricado por idéia do Reverendo Padre Diogo Soares, da Companhia de Jesus". Tal evento foi atendido pelo Conde Governador, de toda a Nobreza e Senado da Câmara e povo em geral.

A festividade do Triunfo Eucarístico encerrou-se com nove dias de eventos seculares:

28 de maio (quinta-feira à tarde): cavalhada

29 de maio (sexta-feira à noite): comédia

30 de maio (sábado à tarde): touro

31 de maio (domingo à tarde): cavalhada

1 de junho (segunda-feira à noite): comédia

2 de junho (terça-feira à tarde): touro

3 de junho (quarta-feira à tarde): cavalhada

4 de junho (quinta-feira à noite): comédia

5 de junho (sexta-feira à tarde): touro 
Esses nove dias contaram com a assistência do Conde Governador, da nobreza secular e eclesiástica, e do povo em geral. Houve serenatas e banquetes todas as noites nas casas da paróquia de Ouro Preto, promovidos pelo Conde Governador. As comédias encenadas foram El secreto a vozes, El Principe prodigioso e El amor criado.

Uma análise da procissão usando o conceito diferencial de Turner entre ritual e cerimônia, o primeiro como transformador e o segundo como confirmador, mostra que o Triunfo Eucarístico de 1733 continha ambos. A procissão dividiu-se em duas partes, a primeira, que poderia ser considerada a seção pagã, e a segunda, que seria a seção sagrada. A primeira seção abre com a dança dramática dos Turcos e Cristãos anunciando logo no começo qual era o tema da procissão, nomeadamente, o tema da conversão. A dança dos Romeiros que segue, representa a prática popular do catolicismo, cheia de crenças, atos e objetos mágicos que nem sempre são considerados pela religião oficial como um entendimento adequado do catolicismo, mas tendendo à "superstição"18. É bem provável que esse seja o motivo deste grupo de devotos católicos estarem situados na seção pagã da procissão. Entretanto, a legitimidade religiosa dos romeiros não foi completamente negada, já que eles estavam sujeitos à purificação pelo efeito simbólico transformador desta seção. O próximo segmento composto de músicos encena o episódio da tentação da serpente, que causou a expulsão de Adão e Eva do Paraíso por causa do pecado capital. A apresentação alegórica, combinada com narração dramática deste episódio do Antigo Testamento, tem propósito educacional e pode ser considerada a forma verbal de persuasão mais explícita desta seção. A alegoria dos Quatro Ventos prenuncia o triunfo do catolicismo nos quatro cantos do mundo e é, por analogia (conforme exposto anteriormente, onde discutimos o Padroado e as Festas Maiores), também uma metáfora do espírito conquistador português. Além disso, a onipresença do Deus católico é uma metáfora da onipresença do Rei português. A alegoria da Fama representa o futuro e prenuncia boa ou má fortuna; o letreiro que 
a Fama levava na procissão anunciava a vitória do dogma católico. O triunfo do catolicismo é reforçado pelos auspiciosos poemas recitados pelos pagens. A música tocada em alternância entre o "Alemão" e os "negros choromeleiros" foi muito provavelmente secular, dada a natureza pagã desta seção. Os escravos negros representados pelos choromeleiros figuram ali como pagãos que devem ser convertidos ao catolicismo. A figura de Ouro Preto, representando a vizinhança da nova Igreja Matriz, aparece nesta seção provavelmente por causa do valor secular desta pedra preciosa, abundante naquelas vizinhanças. A bandeja cheia de diamantes simboliza o valor monetário dos diamantes e o poder econômico daquele bairro. Esse tipo de simbolismo também se aplica à figura de Ouro Fino e à representação da vila como um todo, entre as duas colinas. O valor material dos metais e pedras preciosas encontrados na área tinha que ser transformado em algo com valor religioso. Tais símbolos tinham também um propósito educacional e implicavam analogamente o tema da conversão. Por sua qualidade de expressar idéias abstratas através de formas concretas, tais figuras são alegorias.

A alegoria dos Sete Planetas simboliza velhas crenças, ou, como diz Machado, "a falácia da Idolatria antiga". O sistema astronômico usado neste segmento é anterior ao sistema de Copérnico, o qual havia provado que o Sol é uma estrela e não um planeta. A "estrela d'alva" e a "estrela vespertina", tomadas como duas estrelas diferentes, eram na verdade uma só, e não uma estrela, mas o planeta Vênus. O século XVIII conhecia seis planetas: Mercúrio, Vênus, Terra, Marte, Júpiter e Saturno. Esta alegoria implica claramente a contribuição da ciência aos navegadores ibéricos que descobriram o Novo Mundo. No entanto, não há confronto entre catolicismo e ciência, mas um ajustamento e reconciliação através do reconhecimento de que a verdade católica é superior à verdade científica. A efemeridade da verdade da ciência fecha a seção pagã, contrastando com a figura da Igreja Matriz do Pilar, que faz a transição para a seção sagrada da procissão, a qual culmina com o triunfo da verdade católica. Este é o significado 
do Triunfo Eucarístico. À natureza transformadora da primeira seção é encenada simbolicamente desde o início com a dança dos Mouros e Cristãos e atinge seu momento mais intenso quando a figura da Matriz do Pilar aparece no final da seção pagã, estabelecendo o templo do Deus católico como o espaço para conversão e cultivo do catolicismo. A sentença de Machado, transcrita antes do item VIII do sumário apresentado anteriormente neste artigo, expressa uma percepção coetânea da natureza transformadora desta seção, que encenou simbolicamente o momento de conversão dos pagãos e o triunfo do catolicismo.

Considerando a procissão como uma representação simbólica de um "rito de passagem", a primeira seção pode ser vista como a fase "pré-liminar" de distanciamento da realidade aceita. A figura da Igreja Matriz do Pilar representa o momento de transição para uma nova fase e encena simbolicamente o "espaço liminar", no qual a verdade católica é atemporal e eterna, e no qual todos os seres humanos convertidos são igualmente filhos de Deus e sujeitos às mesmas leis divinas. A segunda seção pode ser considerada a fase "pós-liminar" de agregação, depois da conversão ao catolicismo, onde apenas pessoas convertidas participam. A seção sagrada é, portanto, o lugar para pessoas "autenticamente" religiosas adorarem o Deus católico.

O jogo-simbólico da primeira seção da procissão é construído com alegorias. Esteticamente falando, tais alegorias fazem uso amplo do ornamento, chamado "adorno" por Machado, do princípio barroco da varietas, percebido como "variedade e novidade para os olhos". A função do ornamento na estética barroca não é complementar mas essencial à densidade de expressão, abundância de significado, estímulo sensorial e ambigüidade. Varietas, êxtase sensorial e abundância de significado levam ao fenômeno de "estremecimento" ou "estranhamento"19, um espaço não-ordinário cuja suspensão de tempo e ruptura de ordem pode ser relacionada com o conceito de "liminaridade" de Turner. Por outro lado, a segunda seção da procissão não usa alegorias mas símbolos e reestabelece a ordem normal, eliminando o êxtase sensorial 
provocado pelo caráter maravilhoso da seção precedente. Ao invés do espetacular desfile de tipo carnavalesco da seção pagã, a seção sagrada mostra uma seqüência de irmandades, pessoas religiosas, o clero e a nobreza, encenando gesto solene e reverente sem nenhum apelo sensorial. Alegorias são substituídas por símbolos católicos, como imagens de santos, cruz, bandeiras, velas e a custódia do Sacramento Eucaristia. Todos esses objetos rituais são carregados de significado, tanto pelo sistema mitológico católico geral, como também pela história local ${ }^{20}$.

Um ponto de discussão interessante da segunda parte da procissão de 1733 é a ordem na qual irmandades e participantes aparecem. Como referimos anteriormente, o texto canônico determinava que a seqüência das irmandades em procissões seguisse a hierarquia entre elas, isto é, Ordens Terceiras, Arquiconfrarias, Confrarias e Irmandades, e Pias Uniões, em ordem descendente de importância. Parece claro que o procedimento normal é colocar os participantes mais importantes no começo da procissão, em ordem decrescente de importância. Entretanto, nesta procissão do Triunfo Eucarístico, de 1733, não se obedeceu a essa norma. A sessão sagrada da procissão abriu com as irmandades e grupos menos importantes e fechou com os mais importantes. Essa inversão não significa que se tenha estabelecido um "espaço liminar", nem tampouco inversão simbólica da ordem social; não se constituiu, portanto, um "ritual de inversão de status" (TURNER, 1969: 167; para uma discussão mais extensa do conceito, ver capítulo 5). Pelo contrário, nesse contexto ritual específico, a seqüência das irmandades estendeu o tema da conversão da primeira para a segunda seção e estabeleceu a ordem social a ser legitimada. A primeira irmandade foi a dos mulatos de São José, grupo étnico ainda sem poder na década de 1730. Esta foi seguida pela irmandade do Rosário dos Pretos, representando o grupo étnico mais numeroso da vila de então, e depois a de Santo Antônio, provavelmente uma irmandade de brancos de classe baixa. A nobreza aposentada apareceu numa posição que mostra como o desligamento do poder político implicava perda de prestígio social. Depois da irmandade 
do Rosário dos Brancos, apareceu a primeira irmandade realmente importante durante a década de 1730 , sob a proteção da padroeira do reino de Portugal, N. Sra. da Conceição. A irmandade sob a proteção da padroeira da nova Igreja Matriz, N. Sra. do Pilar, veio logo antes da última irmandade do Santíssimo Sacramento, a qual, além de concentrar a nobreza da vila, gozava de preferência nas procissões de Corpus Christi (Triunfo Eucarístico). A seção sagrada culminou com a custódia da Eucaristia levada pela autoridade religiosa do Reverendo Vigário da Matriz, simbolizando o triunfo da verdade católica sobre a falsidade. O Divino Sacramento, nas mãos do sacerdote e seguido pelas autoridades políticas, simbolizava analogamente o triunfo da ordem colonial. $O$ tema desta seção foi o triunfo da verdade católica, que se tornou a metáfora da confirmação do poder temporal. O Divino Sacramento representou simbolicamente o rei distante mas reinante. A parte sagrada da procissão superpôs funções transformadora e confirmadora. A aparição de irmandades de grupos sociais inferiores primeiro e, depois, gradativamente, os superiores; se tivesse isolada da primeira seção (profana) teria apenas função confirmadora (cerimônia), pois estaria expondo e legitimando ritualisticamente a hierarquia social. Porém, como exposto acima, o tema da conversão da primeira seção, que instituiu um ritual de elevação, contaminou a segunda seção. Portanto, esta seqüência hierárquica das irmandades, ao mesmo tempo que expõe e confirma a ordem social, função principal da segunda seção da procissão, repercute num plano secundário o rito de passagem do pagão para o cada vez mais cristão, que se iniciara na primeira seção. A função confirmadora da segunda seção se cristaliza com as autoridades religiosas e políticas encenando o triunfo do sistema do Padroado. Enquanto a seção pagã da procissão foi alegórica, a seção sagrada foi simbólica, e ambas combinadas resultaram na grande metáfora da conversão, que culminou com a confirmação da ordem social. O Triunfo Eucarístico de 1733 consistiu, portanto, numa superposição de ritual (simbolicamente transformador) e cerimônia (simbolicamente confirmadora). 
Tal ritual-cerimônia legitimou a hegemonia da Igreja Católica e do Rei e, em certa medida, foi uma modalidade de doutrinação com e sem palavras, pois envolvia enunciações, alegorias e uma série de objetos e atos rituais, todos parte do jogo simbólico de que fala Ávilla (1971). O Triunfo Eucarístico constituiu um evento cuja mensagem persuasiva foi, em última instância, a sacralização do poder temporal através do divino e a confirmação do poder religioso através de dogmas que estavam além da razão humana, acima de qualquer explanação; estavam ali e eram inegáveis, absolutos e verdade última. A natureza dogmática da religião católica, extensiva ao poder monárquico, explica porque rituais e cerimônias eram construídos segundo os princípios barrocos de persuasão, com amplo uso de alegorias, símbolos e metáforas, e efetivados através de jogos simbólicos mais do que de raciocínio e razão.

\section{NOTAS}

1. Todas as citações de Bruneau são tradução da autora.

2. Para discussão do conceito, ver TURNER, 1969: 94.

3. Todas as citações de Turner são tradução da autora.

4. Tradução da autora.

5. De agora em diante, o termo "irmandade" em letra minúscula se refere indistintamente a essas quatro catcgorias. Quando a diferenciação hicrárquica for necessária, este texto usará a palavra em letra maiúscula.

6. Ver catálogos: BARBOSA, 1979; DUPRAT \& BALTAZAR, 1991; DUPRAT \& BALTAZAR, 1991 e 1994.

7. A Irmandade de Santa Cecília de Lisboa, Portugal, foi fundada em 1603; a de Olinda, Pernambuco, em 1760; a de Salvador, Bahia, em 1785; a de Recife, Pernambuco, em 1789; a do Rio de Janeiro existiu pelo menos desde 1815 , talvez fundada em 1808 ou até mesmo depois de 1765 , quando o Rio de Janeiro se tornou capital do Brasil.

8. Não é possível, no momento, empreender uma discussão consistente sobre a representatividade do autor do Triunfo Eucarístico, pois existe muito pouca informação sobre Simão Ferreira Machado e as circunstâncias e motivações específicas para escrever aquela crônica. A única informação biográfica é apresentada no frontispício daquela obra, e diz que 0 autor nascera em Lisboa e residia em Minas Gerais. Existem 3 hipóteses diferentes concernentes à sua identidade: Augusto Lima Júnior afirma 
que Simão Ferreira Machado foi um homem rico de Minas Gerais que serviu ao governo português na corte de Roma e foi ao Brasil acompanhando Dom André de Melo e Castro, o Conde de Galveas então nomeado Governador das Minas Gerais. Feu de Carvalho diz que Simão Ferreira Machado pode ter sido o pseudônimo do cartógrafo jesuíta Diogo Soares. Helio Gravatá encontrou um cirurgião chamado Simão Ferreira Machado, vivendo cm São Paulo 14 anos depois, mas não existe evidência de que eles fossem a mesma pessoa. Discussão mais ampla sobre a identidade do autor do Triunfo Eucarístico se encontra em Ávilla, 1967: 295-298. Todas essas hipóteses mostram, entretanto, que o autor do Triunfo Eucarístico foi um português letrado que muito provavelmente viveu entre a nobreza.

9. Johan HUIZINGA, Homo Ludens, trad. Eugenio Imaz, Buenos Aires, Emecé, 1957.

10. O Triunfo Eucarístico foi transcrito na Revista do Arquivo Público Mineiro, VI, p. 985-1016. Além dessa transcrição, Ávilla, 1967 vol. I, publicou um fac-simile da edição-princeps.

11. O dia da Ascensão é 21 dias antes de Corpus Christi, ou 40 dias depois do domingo de Páscoa. Corpus Christi incide na quinta-feira após o oitavo domingo que se segue à Páscoa. No entanto, a procissão do Triunfo Eucarístico de 1733 não foi realizada na quinta-feira e, projetando 21 dias precedentes de 21 ou 23 de maio, o dia da Ascensão seria a 30 de abril ou 2 de maio. Tais possibilidades parecem não coadunar com a narração dos fatos segundo Machado.

12. O posto de alferes durante o período colonial e imperial corresponde ao atual posto de segundo-tenente.

13. Sobre o Alemão, ver LANGE, 1966: 22-3.

14. Sobre choromeleiros, ver LANGE, 1966: 23-5.

15. Segundo a mitologia, o mensageiro dos deuses (conf. ÁVILLA, 1967, vol. I: 294).

16. Insígnia do deus Mercúrio: bastão com duas serpentes enroscadas e com duas asas na extremidade superior.

17. Lúcifer é a cstrela Vênus quando sc levanta pela manhã no horizonte (conf. ÁVILLA, 1967, vol. I: 291).

18. O termo "superstição" deve ser tomado aqui dentro do sistema religioso oficial da Igreja Católica.

19. Para uma discussão mais profunda do fenômeno de "estranhamento" ou "estremecimento", ver Á VILLA, 1971, particularmente capítulos 3 e 4.

20. Não há espaço neste artigo para detalhar os símbolos de especial relevância local, sobretudo os santos cujas imagens aparecem na procissão em discussão. 


\section{BIBLIOGRAFIA}

ARAUJO, Alceu Maynard. Folclore Nacional. São Paulo, Melhoramentos, 1964. $2 \mathrm{v}$.

ÁVILLA, Affonso. Residuos Seiscentistas em Minas: textos do século do ouro e as projeções do mundo barroco. Belo Horizonte, Centro de Estudos Mineiros, 1967. $2 \mathrm{v}$. pectiva, 1980.

AZZI, Riolando. A cristandade colonial: um projeto autoritário. São Paulo, Paulinas, 1987.

BARBOSA, Elmer Correia. O ciclo do Ouro, o tempo e a música do barroco católico. Rio de Janeiro, PUC/ Xerox, 1979.

BRUNEAU, Thomas C. The political transformation of the Brazilian Catholic Church. Cambridge University Press, 1982.

CARRATO, José Ferreira. Igreja, Iluminismo e Escola Mineiras Coloniais. São Paulo, Companhia Editora Nacional/ EDUSP, 1968.

DUPRAT, Regis \& Baltazar, Carlos Alberto. Acervo de manuscritos musicais: Museu da Inconfidência de Ouro Preto: compositores mineiros dos séculos XVIII eXIX, vol. I. Belo Horizonte, Universidade Federal de Minas Gerais, 1991.

- Acervo de manuscritos musicais: Museu da Inconfidência de Ouro Preto: compositores não-mineiros dos séculos XVIII e XIX, vol II. Belo Horizonte, Universidade Federal de Minas Gerais, 1994.

HOLlandA, Sergio Buarque (ed.). História Geral da Civilização Brasileira (A Época Colonial), Tomo I, $2^{\circ}$ vol. São Paulo, Difusão Européia do Livro, 1973.

LACOMBE, Américo Jacobina. A obra histórica do padre IIoornaert. Rio de Janeiro, Agir, 1983.

LANGE, Curt. A organização musical durante o periodo colonial brasileiro. Separata do v. 4 das ACTAS do V Colóquio Internacional de Estudos Luso-Brasileiros. Coimbra, Universidade de Coimbra, 1966.

"A música barroca". In: Hollanda, 1973, Tomo I, 2 vol. p. $121-144$.

LIMA JÚNIOR, Augusto. A Capitania das Minas Gerais: Origens e Formação. 3.a ed., Belo Horizonte, Instituto Nacional de História, 1965.

LOPES, Francisco Antônio. Os Palácios de Vila Rica. Belo Horizonte, Imprensa Nacional, 1955.

MACHADO, Simão Ferreira. "Triumpho Eucharistico". In: Revista do Arquivo Público Mineiro, VI, p. 985-1016.

NOGUEIRA, Canon Eurico. Church and State in Portugal. Portugal, SNI, 1941. 
SALLES, Fritz Teixeira Associações religiosas no ciclo do ouro: introdução ao estudo do comportamento social das Irmandades de Minas no século XVIII. Belo Horizonte, Universidade de Minas Gerais, 1963. . Vila Rica do Pilar. Belo Horizontc, Itatiaia/ São Paulo, EDUSP, 1982.

SCHWARTZ, 1995. "The Portuguese heritage: adaptability". In: Brazilian Mozaic: Portraits of a Diverse People and Culture (ed. G. Harvey Summ). Wilmington, Scholarly Resources, 1995.

TORRES, João Camilo de Oliveira. História das idéias religiosas no Brasil (a Igreja e a sociedade hrasileira). São Paulo, Grijalbo, 1968.

TRINDADE, Conego Raimundo. Instituições de Igrejas no Bispado de Mariana. D.P.H.A.N. $1^{\circ}$ 13. Rio de Janeiro, MEC, 1945. . S. Francisco de Assis de Ouro Preto. D.P.H.A.N. $n^{\circ} 17$. Rio de Janeiro, MEC, 1951.

TURNER, Victor. The Ritual Process. Chicago, Aldine Pub. Co., 1969.

VASCONCELLOS, Diogo. História antiga das Minas Gerais (1703-1720). Rio de Janeiro. INL-MES-Imprensa Nacional, 1948. 2 v.

Maria Alice Volpe é doutoranda em musicologia na Universidade do Texas. 